\title{
Prognostic significance of immune cells in non-small cell lung cancer: meta-analysis
}

\author{
Ross A. Soo ${ }^{1,2,5}$, Zhaojin Chen ${ }^{3}$, Rebecca Siew Yan Teng ${ }^{4}$, Hon-Lyn Tan ${ }^{1}$, Barry \\ Iacopetta ${ }^{5}$, Bee Choo Tai $^{3,6}$ and Richie Soong ${ }^{2,7}$ \\ ${ }^{1}$ Department of Haematology-Oncology, National University Health System, Singapore \\ ${ }^{2}$ Cancer Science Institute of Singapore, National University of Singapore, Singapore \\ ${ }^{3}$ Investigational Medicine Unit, National University Health System, Singapore \\ ${ }^{4}$ Yong Loo Lin School of Medicine, National University of Singapore, Singapore \\ ${ }^{5}$ School of Surgery, The University of Western Australia, Perth, Australia \\ ${ }^{6}$ Saw Swee Hock School of Public Health, National University of Singapore, Singapore \\ ${ }^{7}$ Department of Pathology, National University Health System, Singapore \\ Correspondence to: Ross A. Soo, email: ross_soo@nuhs.edu.sg \\ Keywords: non-small cell lung cancer; immune cells; dendritic cells; tumor associated macrophages; mast cells \\ Received: December 29, $2017 \quad$ Accepted: March 06, $2018 \quad$ Published: May 15, 2018 \\ Copyright: Soo et al. This is an open-access article distributed under the terms of the Creative Commons Attribution License 3.0 \\ (CC BY 3.0), which permits unrestricted use, distribution, and reproduction in any medium, provided the original author and source \\ are credited.
}

\section{ABSTRACT}

Background: Tumor-associated immune cells are prognostic in non-small cell lung cancer (NSCLC) but findings have been conflicting.

Objectives: To determine the prognostic role of immune cells according to localization in NSCLC patients.

Methods: A systematic literature review and meta-analysis was performed on dendritic cell (DC), tumor associated macrophages (TAM), mast cells (MC), natural killer (NK) cells, T and B cells and tumor CTLA-4 and PD-L1 studies.

Results: We analysed 96 articles ( $n=21,752$ patients). Improved outcomes were seen with increased tumor DCs (overall survival (OS) hazard ratio (HR) 0.55 ; $95 \%$ confidence interval (CI) $0.44-0.68$ ), NK cells (OS HR 0.45; 0.31-0.65), TAMs (OS HR $0.33 ; 0.17-0.62$ ), M1 TAMs (OS HR 0.10; 0.05-0.21), CD3+ T cells (disease specific survival (DSS) HR 0.64; 0.48-0.86), CD8+ T cells (OS HR 0.78; 0.66-0.93), B cells (OS HR 0.65; 0.42-0.99) and with increased stroma DC (DSS HR 0.62; 0.47-0.83), NK cells (DSS HR 0.51; 0.32-0.82), M1 TAMs (OS HR 0.63; 0.42-0.94), CD4+ T cells (OS HR 0.45; 0.21-0.94), CD8+ T cells (OS HR 0.77; 0.69-0.86) and B cells (OS HR 0.74;0.56-0.99). Poor outcomes were seen with stromal M2 TAMs (OS HR 1.44; 1.06-1.96) and Tregs (relapse free survival (RFS) HR 1.80; 1.34-2.43). Tumor PD-L1 was associated with worse OS (1.40; 1.20-1.69), RFS (1.67) and DFS (1.24).

Conclusion: Tumor and stroma DC, NK cells, M1 TAMs, CD8+ T cells and B cells were associated with improved prognosis and tumor PD-L1, stromal M2 TAMs and Treg cells had poorer prognosis. Higher quality studies are required for confirmation.

\section{INTRODUCTION}

Lung cancer is one of the most common malignancies globally, accounting for 1.5 million cases annually. It is also the leading cause of cancer deaths globally, causing 1.3 million deaths annually [1]. The tumor microenvironment has a major role in influencing cancer development [2], of which immune cells are considered to contribute to tumor destruction, as well as tumor development by promoting growth and invasion $[3,4]$.

In recent times, a major advance in the treatment of non-small cell lung cancer (NSCLC) has been the use 
of immunotherapy, such as immune checkpoint inhibitors targeting cytotoxic T lymphocyte antigen-4 (CTLA-4), programmed death receptor-1 (PD-1) and programmed death receptor ligand-1 (PD-L1) [5]. In the advanced stage NSCLC setting, many PD-1/PD-L1 inhibitors have been approved for use [6], although results from trials in the resected tumor setting have been less encouraging [7].

The potential of the immune system to contribute functionally to both tumor elimination and promotion, and the observed significant effects of its modulation through immunotherapy, have supported that the immune system can be a significant determinant of the outcomes of NSCLC patients. As such, numerous studies have investigated the prognostic and predictive significance of many different cell types of the immune system over the years [4]. The different immune cell types have included mast cells, dendritic cells, natural killer cells, macrophages, neutrophils of the innate immune system, $\mathrm{T}$ and $\mathrm{B}$ lymphocytes of the adaptive immune system, as well as CTLA-4 and PD-L1expressing cells targeted by immunotherapy. In many cases, specific subtypes of immune cells, such as M1 and M2 macrophages, and $\mathrm{CD} 3+, \mathrm{CD} 4+, \mathrm{CD} 8+$, and regulatory $\mathrm{T}$ cells have been examined. Moreover, assessment according to localization of the immune cells in tumor parenchyma or stroma has also been performed. This is based on the observed varied presence of these cells in the tissue compartments, and associated functional implications.

Findings from such reports have been numerous and varied according to immune cell type, outcome endpoint, tissue localization, study quality, as well as results. This study was undertaken with the goal of consolidating knowledge on the prognostic significance of the many immune cell types in NSCLC, and according to investigated co-factors.

\section{METHODS}

\section{Search strategy}

Meta-analysis was conducted according to the guidelines of the Systematic Reviews and Meta-Analyses (PRISMA) [8]. Relevant articles were identified through a systematic search of PUBMED using the MeSH terms: "Immune cell type" AND "lung neoplasm" limited to "Human", "English". MeSH terms for the immune cell types were "mast cells", "macrophage", "dendritic cell", "NK cell”, "regulatory T cell”, "CD3 T-lymphocyte", "CD4 T-lymphocyte", "CD8 T-lymphocyte", "B cell”, "CTLA4 antigen" and "Antigen, CD274" (PD-L1). Articles published up to 7 July 2017 were included in our search.

\section{Inclusion and exclusion criteria}

The inclusion criteria for articles were those that reported on samples from patients with primary lung tumors with NSCLC, having no systemic treatment or radiation therapy prior to sample collection, and sufficient prognostic information to determine pooled Hazard Ratios (HR). Where HRs were not reported, included studies had to have sufficient information to extrapolate HR. The exclusion criteria included studies on blood or other body fluids or pre-clinical models, studies on the optimization of immunohistochemistry (IHC) or quantitative immunoflurorescence (QIF) methods, or using non-IHC/QIF based methods to detect immune cells, as well as letters and case reports. References cited in retrieved articles were checked for additional relevant articles. Data from other reviews and meta-analyses were not included, but articles identified through references cited were reviewed. Irrelevant and/or duplicate studies were removed by manual curation. Study eligibility was assessed independently by two authors (RAS and ZC).

\section{Data extraction}

Two investigators (RAS and ZC) independently extracted the data. The following details were extracted from each study: first author, publication year, PMID, country of origin of the study population, immune cell studied, phenotype, markers used to define immune cell type, localization of immune cells (defined as "tumor", "stroma" or, if the localization was unspecified, "general" compartment), sample size, number of events, tumor stage, treatment setting, and histology (adenocarcinoma, squamous cell carcinoma or mixed). For study methodology, data was collected on the assay used, tissue sample used (full tissue sections or tissue microarray), antibodies used, scoring method and thresholds used to define expression. Survival outcomes annotated included disease-free survival (DFS), relapse-free survival (RFS), disease-specific survival (DSS) and overall survival (OS).

\section{Assessment of study quality and risk of bias}

RAS and HLT independently assessed study quality according to the criteria developed by McShane 2005 and Hayes $[9,10]$ for tumor marker prognostic studies. In brief, the criteria assessed seven domains including: inclusion and exclusion criteria, prospective or retrospective study design, patient and tumor characteristics, method or assay description, outcome measures defined, patient follow up and number of patients lost to follow-up or otherwise unavailable for analysis.

\section{Statistical analysis}

The prognostic effect of an immune cell was quantified by HR, defined as the relative hazard of death or disease progression of patients with high or positive immune cell levels against those with low or negative immune cell levels. Where HRs were not reported, they were estimated using hazard ratio, odds ratio, or the ratio of median survival, as proposed by Parmar [11]. 
Stratified analysis was conducted according to localization (tumor, stroma, general), or phenotype of immune cells. A meta-analysis was performed when there were at least two studies in a stratum. Therefore, a single study with a reported HR in an analytic stratum was not analyzed. For studies with considerable heterogeneity, studies were modelled for random-effects, according to the methods of DerSimonian and Laird [12]. Otherwise, a fixed-effect model was used. Heterogeneity was considered to be low, moderate, and high for $\mathrm{I}^{2}$ values of $25-50 \%, 50-75 \%$, and $\geq 75 \%$, respectively [13]. Results for each immune cell type were displayed using a forest plot. A funnel plot was constructed to visualize small-study effects and possible publication bias for a stratum with five or more studies. To test for small-study effect, the Egger's test was subsequently performed when there were at least 10 studies in a stratum. Median survival times were derived from the Kaplan-Meier survival curves using DigitizeIt 2.2. All analyses were performed using StataSE14 (StataCorp LP, College Station, Texas) by assuming a twosided statistical test with 5\% significance level.

\section{RESULTS}

A systematic search of PubMed and referenced articles resulted in 3,291 records, from which 96 individual studies, assessing 21,752 patients, were eligible for metaanalyses (Supplementary Tables 1-2, Supplementary Figure 1). The majority of studies were from East Asia (61, $64 \%$ ) and mixed NSCLC histology (60, 63\%). IHC was used in $92(96 \%)$ of studies, and full tissue sections were used in $67(70 \%)$. The average study quality score for all studies was 4.7 .

\section{Mast cells}

Mast cells (MC) play a key role in allergic diseases but are also involved in immune responses. Depending on the type of solid tumor, mast cells can enhance adaptive immunity but also play a key role in tumor angiogenesis, tumor invasion, and immune suppression [14]. Ten studies were analysed [15-24]. (Supplementary Table 1 and 2, Supplementary Figure 1A). The number of studies analysed per stratum ranged from two to three (Table 1). Early studies reported MC counts without consideration of tumor localisation (Supplementary Table 2). Three out of four studies reported increased MC was associated with a worse OS, however the associations did not reach statistical significance in pooled analysis (HR 2.23; 95\% CI 0.61-8.11) (Table 1, Figure 1A). Later studies assessed outcomes according to localisation, and reported $\mathrm{MC}$ were not significantly associated with OS in the tumor (HR 1.21; 0.58-2.51) or stroma (HR1.34; 0.99-1.81). A high degree of heterogeneity was seen in studies on OS according to general $\left(\mathrm{I}^{2} 94.1 \%, p<0.001\right)$ and tumor $\left(\mathrm{I}^{2} 74.1 \%, p=0.021\right)$ localisation.

\section{Dendritic cells}

Dendritic cells (DC) are the most potent antigen presenting cells and regulate the immune system to respond to foreign antigens while avoiding autoimmunity and therefore are important in cancer, generating both immunity and tolerance [25]. Eight studies (were suitable for analysis (Supplementary Tables 1, 2, Supplementary Figure 1B). The average quality score was 4.5 (Supplementary Table 1) [24, 26-32]. On pooled analysis, the HR for OS for general DC was 0.65 (0.30-1.38) (Table 1, Figure 1B). Inoshima et al. first reported high DCs in the tumor compartment was associated with longer OS [27]. In pooled analysis, increased tumor DC was prognostic for OS (HR 0.55; 0.44-0.68) but not for DSS (HR 0.80; 0.53-1.20). In contrast, stromal DC was significantly associated with DSS (HR $0.62 ; 0.47-0.83$ ). Study heterogeneity was generally low in the studies examined for OS in tumor and DSS in the tumor and stroma. Funnel plot analysis was not performed as there was an inadequate number of publications per stratum.

\section{Natural killer (NK) cells}

Natural killer (NK) cells are the major effector cells of the innate immune system, and have an important role in the immune response against cancer [33]. Only five studies were suitable for pooled analysis (Supplementary Tables 1, 2 Supplementary Figure 1C) [24, 28, 34-36]. Pooled analysis revealed increased tumor NK cells were associated with an improved OS (HR 0.45; 0.31-0.65) but not DSS (HR 2.29; 0.62-8.69), whereas stromal NK cells were associated with better DSS (HR 0.51; 0.32-0.82) (Table 1, Figure 1C). Study heterogeneity was low. As the number of publications per stratum was only 2 or 3 , further studies of adequate sample size should be pursued.

\section{Tumor associated macrophages}

Tumor associated macrophages (TAMs) are part of the innate immune system and have an essential function against foreign pathogens [37]. Eighteen studies were analysed (Supplementary Tables 1, 2, Supplementary Figure 1D) $[20,21,24,28,29,38-50]$. The number of studies per stratum was 2-5 (Table 1). Initial studies reported on tumor-associated macrophages (TAM) in the general compartment $[39,40]$ and subsequently the importance of tumor localization was first recognised by Eeroloa et al. who found increased tumoral TAM was associated with an improved OS and DFS [38]. The significance of TAM localization was extended further in a pivotal paper that reported increased tumor TAM had an improved OS whereas stromal TAMs had worse OS [21].

In our pooled analysis, increased TAMs in general had worse OS (HR 2.32; 1.38-3.90) (Table 1, Figure 2A). When analysed according to localization, increased TAMs in the tumor compartment was associated with a 
Table 1: Summary of hazard ratios, sample sizes and average quality scores from pooled analyses for cell types according to cellular localization

\begin{tabular}{|c|c|c|c|c|c|c|}
\hline & \multicolumn{2}{|c|}{ General } & \multicolumn{2}{|c|}{ Tumor } & \multicolumn{2}{|c|}{ Stroma } \\
\hline & DSS & OS & DSS & OS & DSS & OS \\
\hline Mast cells & NA & $\begin{array}{c}2.23[0.61-8.11] \\
\mathrm{n} 468(4) \mathrm{Q} 4.25\end{array}$ & NA & $\begin{array}{c}1.21[0.58-2.51] \\
\mathrm{n} 630(3) \mathrm{Q} 5.3\end{array}$ & $\begin{array}{c}1.07[0.96-1.20] \\
\text { n390(2) Q5 }\end{array}$ & $\begin{array}{c}1.34[0.99-1.81] \\
\text { (n291(2) Q6.5 }\end{array}$ \\
\hline Dendritic cells & NA & $\begin{array}{c}0.65[0.30-1.38] \\
\mathrm{n} 525(3) \mathrm{Q} 4\end{array}$ & $\begin{array}{c}0.80[0.53-1.20] \\
\text { n390(2) Q5.5 }\end{array}$ & $\begin{array}{c}0.55[0.44-0.68] \\
\text { n534(3) Q4.67 }\end{array}$ & $\begin{array}{c}0.62[0.47-0.83] \\
\text { n390(2) Q2 }\end{array}$ & NA \\
\hline $\begin{array}{l}\text { Natural Killer } \\
\text { cells }\end{array}$ & NA & NA & $\begin{array}{c}2.29[0.61-8.69] \\
\text { n390(2) Q5.5 }\end{array}$ & $\begin{array}{c}0.45[0.31-0.65] \\
\text { n374(3) Q2.67 }\end{array}$ & $\begin{array}{c}0.51[0.32-0.82] \\
\text { n390(2) Q5 }\end{array}$ & NA \\
\hline Macrophages & NA & $\begin{array}{c}2.32[1.38-3.90] \\
\text { n695(5) Q4.2 }\end{array}$ & $\begin{array}{c}0.76[0.50-1.15] \\
\text { n350(2) Q5 }\end{array}$ & $\begin{array}{c}0.33[0.17-0.62] \\
\mathrm{n} 443(4) \mathrm{Q} 5\end{array}$ & $\begin{array}{c}0.79[0.59-1.06] \\
\text { n350(2) Q5 }\end{array}$ & $\begin{array}{c}1.55[1.01-2.37] \\
\mathrm{n} 704(5) \mathrm{Q} 5.4\end{array}$ \\
\hline Macrophages, M1 & NA & NA & NA & $\begin{array}{l}0.10[0.05-0.21] \\
\mathrm{n} 140(2) \mathrm{Q} 4.5\end{array}$ & NA & $\begin{array}{c}0.63[0.42-0.94] \\
\text { n140(2) Q4.5 }\end{array}$ \\
\hline Macrophages, M2 & NA & NA & NA & $\begin{array}{c}0.78[0.35-1.71] \\
\text { n348(3) Q4.67 }\end{array}$ & $\begin{array}{l}2.32[1.66-3.24] \\
\quad \text { n5 } 12(2) \mathrm{Q}^{7}\end{array}$ & $\begin{array}{c}1.44[1.06-1.96] \\
\mathrm{n} 853(5) \mathrm{Q} 5\end{array}$ \\
\hline T cells, CD3+ & NA & $\begin{array}{c}0.72[0.53-0.97] \\
\mathrm{n} 848(4) \mathrm{Q} 4.5\end{array}$ & $\begin{array}{c}0.64[0.48-0.86] \\
\text { n350(2) Q } 5^{2,3}\end{array}$ & $\begin{array}{c}0.88[0.74-1.05] \\
\mathrm{n} 420(3) \mathrm{Q} 3\end{array}$ & $\begin{array}{c}1.13[0.38-3.35] \\
\mathrm{n} 350(2) \mathrm{Q} 5\end{array}$ & $\begin{array}{c}0.86[0.62-1.18] \\
\text { n325(2) Q3 }\end{array}$ \\
\hline T cells, CD4+ & NA & NA & $\begin{array}{c}0.86[0.61-1.21] \\
\mathrm{n} 350(2) \mathrm{Q} 5.5^{4}\end{array}$ & $\begin{array}{c}0.74[0.48-1.15] \\
\text { n678(4) Q4.5 }\end{array}$ & $\begin{array}{c}0.23[0.06-0.95] \\
\text { n350(2) Q5.5 }\end{array}$ & $\begin{array}{c}0.45[0.21-0.94] \\
\text { n358(3) Q5.67 }\end{array}$ \\
\hline T cells, CD8+ & $\begin{array}{c}0.70 \\
{[0.48-1.02]} \\
\text { n554(3) } \\
\text { Q4.34 }\end{array}$ & $\begin{array}{c}0.80[0.56-1.15] \\
\mathrm{n} 1348(6) \mathrm{Q} 4.5\end{array}$ & $\begin{array}{c}0.69[0.50-0.96] \\
\text { n350(2) Q5.5 }\end{array}$ & $\begin{array}{l}0.78[0.66-0.93] \\
\mathrm{n} 2844(9) \mathrm{Q} 4.55\end{array}$ & $\begin{array}{l}0.47[0.36-0.63] \\
\text { n1187(3) Q5.67 }\end{array}$ & $\begin{array}{c}0.77[0.69-0.86] \\
\text { n2157(8) Q5 }\end{array}$ \\
\hline $\mathrm{T}$ cells, regulatory & NA & $\begin{array}{c}1.42[0.78-2.60] \\
\text { n146(2) Q3.5 }\end{array}$ & $\begin{array}{c}1.43[0.69-2.94] \\
\mathrm{n} 578(2) \mathrm{Q} 4^{7}\end{array}$ & $\begin{array}{c}1.00[0.75-1.34] \\
\mathrm{n} 578(2) \mathrm{Q} 4\end{array}$ & $\begin{array}{c}1.80[1.34-2.43] \\
\mathrm{n} 678(3) \mathrm{Q} 4^{7,10}\end{array}$ & $\begin{array}{c}1.43[0.69-2.94] \\
\mathrm{n} 750(5) \mathrm{Q} 4.4\end{array}$ \\
\hline B cells & NA & NA & NA & $\begin{array}{c}0.65[0.42-0.99] \\
\text { n590(2) Q4.5 }\end{array}$ & NA & $\begin{array}{c}0.74[0.56-0.99] \\
\text { n644(2) Q4.5 }\end{array}$ \\
\hline PD-L1 & NA & NA & $\begin{array}{c}1.67[1.22-2.29] \\
\mathrm{n} 2245(10) \mathrm{Q} 4.8^{7,8}\end{array}$ & $\begin{array}{c}1.40[1.20-1.69] \\
\mathrm{n} 8970(35) \mathrm{Q} 5\end{array}$ & NA & NA \\
\hline
\end{tabular}

Results are expressed as pooled HR [95\% confidence limit], number of patients (number of studies), Q (average quality score).

$\mathrm{DFS}$ = disease-free survival, DSS = disease-specific survival, NA = not analyzable, OS = overall survival, RFS = relapse-free survival.

${ }^{1}$ DFS, no DSS available.

${ }^{2} \mathrm{RFS} \mathrm{HR}=0.73[0.40-1.32]$.

${ }^{3} \mathrm{DFS} H \mathrm{HR}=1.01[0.54-1.88]$.

${ }^{4} \mathrm{RFS}$ HR $=1.11[0.73-1.68]$.

${ }^{5} \mathrm{DFS}$ HR $=0.58[0.32-1.04]$.

${ }^{6}$ RFS HR $=1.22[0.82-1.83]$.

${ }^{7} \mathrm{RFS}$, no DSS available.

${ }^{8}$ DFS HR $=1.24[1.01-1.52]$.

${ }^{9} \mathrm{DFS}$ HR $=1.69[1.11-2.55]$.

${ }^{10} \mathrm{DFS}$ HR $=1.24[1.01-1.52]$.

better OS (HR 0.33; 0.17-0.62) whereas stromal TAM was associated with poorer OS (HR $1.55 ; 1.01-2.37$ ). In terms of DSS, TAMs in the tumor (HR 0.76; 0.50-1.15) and stromal (HR 0.79; 0.59-1.06) compartments was not significant (Figure 2A). A high degree of heterogeneity was seen in studies on OS according to general $\left(\mathrm{I}^{2}\right.$ $78.4 \%, p=0.001)$ and tumor $\left(\mathrm{I}^{2} 87.0 \%, p<0.001\right)$ localisation. Funnel plot analysis suggest publication bias on macrophages in general compartment whereas no bias was seen for stroma macrophages (Supplementary Figure $2 \mathrm{~A}$ and $2 \mathrm{~B})$.

Distinct macrophage phenotypes have been described including M1 macrophages that induce host defense, antitumor immunity and inflammatory responses and M2 macrophages reduces inflammation, suppress antitumor immunity and promote angiogenesis [37]. Given the presence of different macrophage phenotypes, we determined the prognostic effect of M1 and M2 macrophages (Table 1, Figure 2B, 2C) and found M1 macrophages was associated with improved OS in the tumor (HR 0.10; $0.05-0.19$ ) stromal M1 and stroma (HR 0.63; 0.42-0.94). Whilst tumor M2 macrophages was not significant for OS, stroma M2 macrophages was associated with a worse OS (HR 1.44; 1.06-1.96) and RFS (HR 2.32; 1.66-3.24).

\section{Neutrophils}

Neutrophils, a key effector immune cell, has a complex role in tumorigenesis [51]. After screening, four full text papers were reviewed $[49,52-54]$ but no 

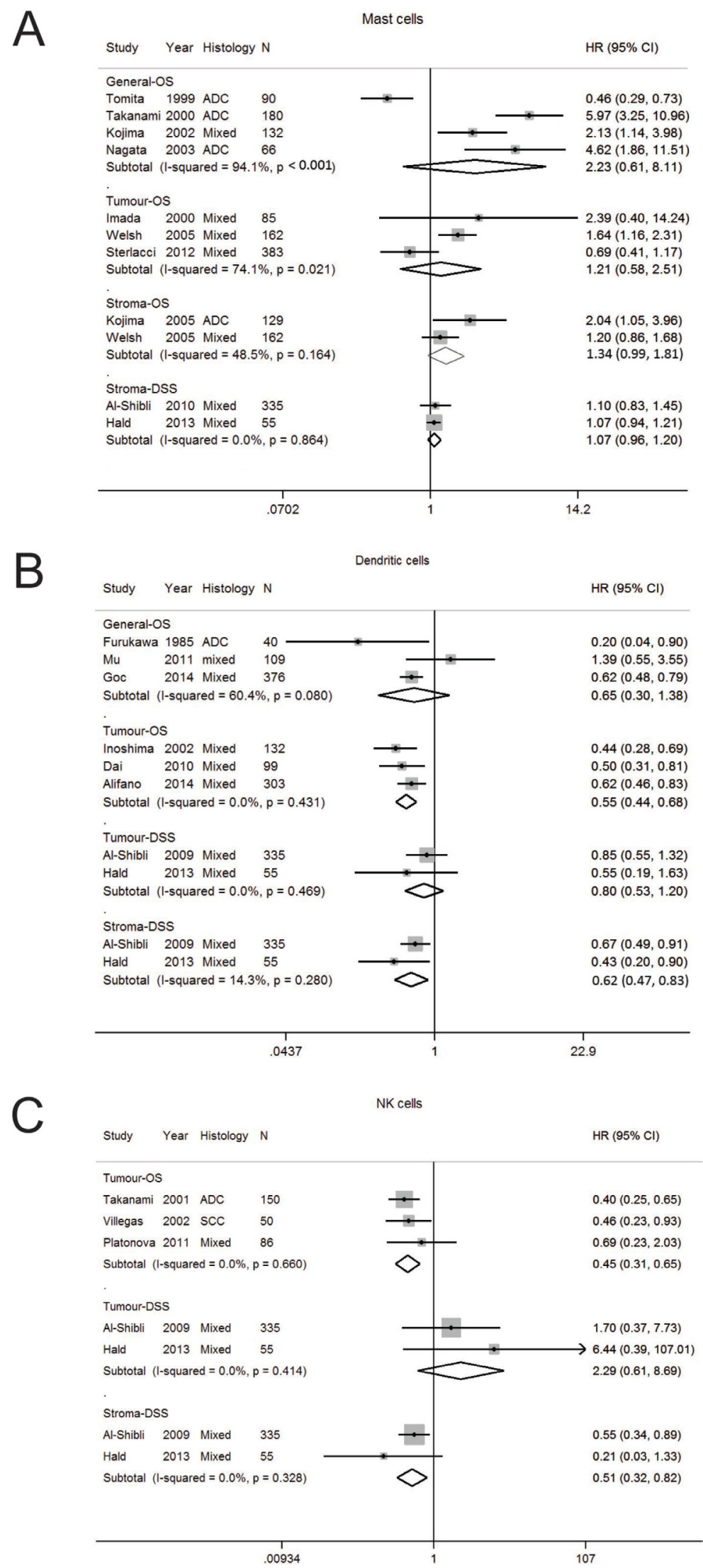

Figure 1: Forest plot of studies assessing (A) Mast cells, (B) dendritic cells, (C) Natural killer cells and survival in patients with non-small cell lung cancer. Adenocarcinoma, ADC; confidence interval, CI; disease specific survival, DSS; hazard ratio, HR; overall survival, OS; programmed cell death-ligand 1, PD-L1; progression free survival, PFS; squamous cell carcinoma, SCC. 
A

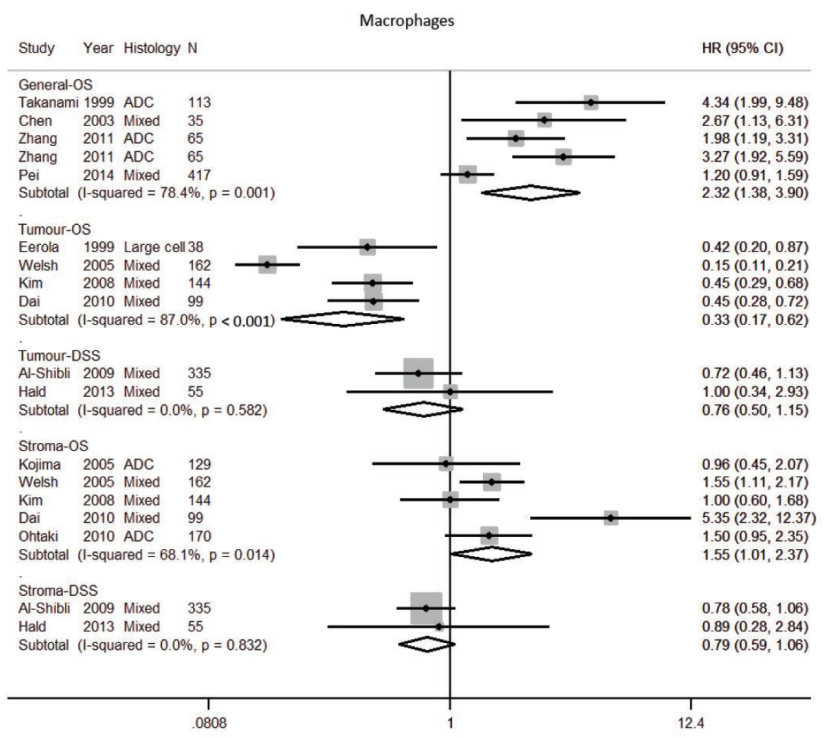

B

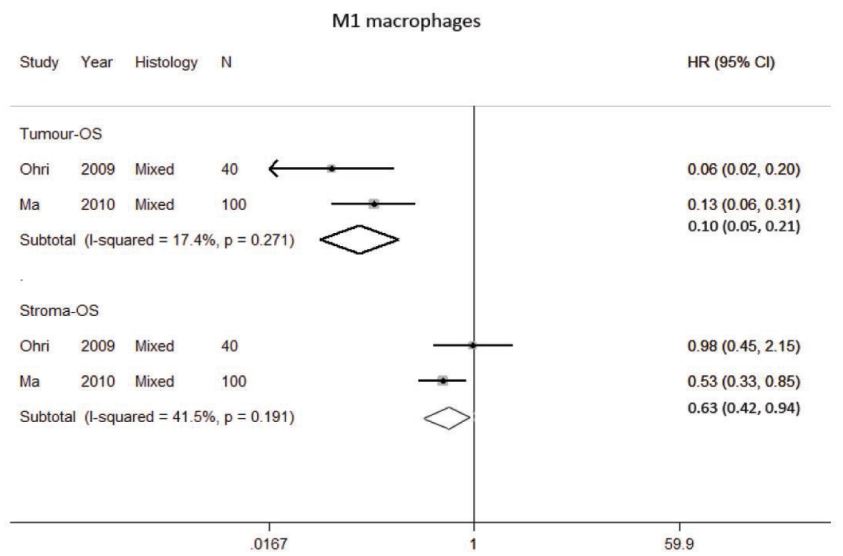

C

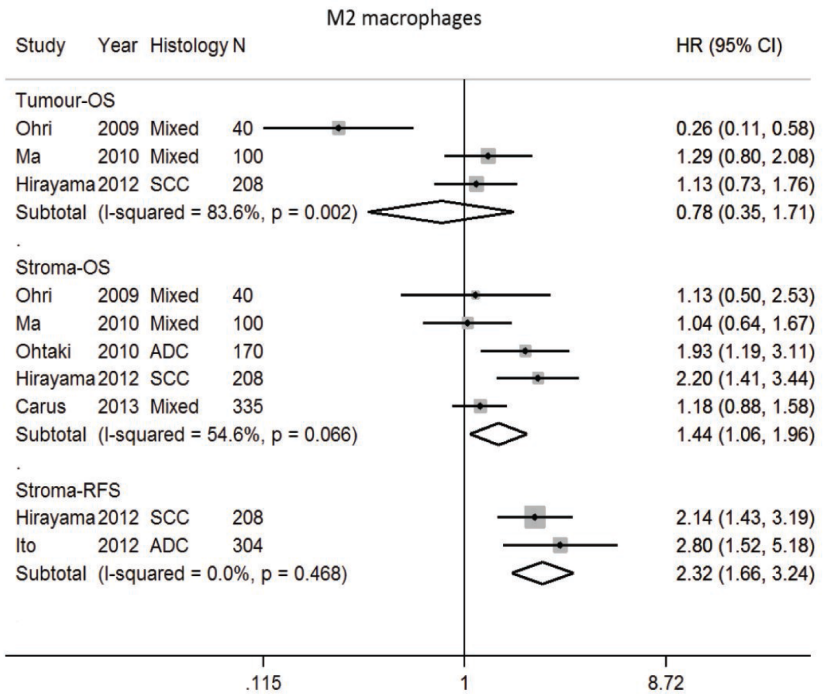

Figure 2: Forest plot of studies assessing (A) Macrophages (B) Macrophages M1 (C) Macrophages M2 and survival in patients with nonsmall cell lung cancer (NSCLC) stratified according to localisation (in general, tumor or stroma compartment). Adenocarcinoma, ADC; confidence interval, CI; disease specific survival, DSS; hazard ratio, HR; overall survival, OS; programmed cell death-ligand 1, PD-L1; progression free survival, PFS; relapse free survival, RFS; squamous cell carcinoma, SCC. 
studies were selected for pooled analysis. One study was excluded as neo-adjuvant chemotherapy was administered in $9 \%$ of patients [54] and three other studies were in a single stratum [49, 52, 53] (Supplementary Table 1, Supplementary Figure 1E). In the first study by Carus et al, increased neutrophils in the tumor and stroma was not associated with RFS or OS [49] whereas in the second study, increased tumor associated neutrophils (TAN) was associated with a poorer DFS [52]. In the third study, high intratumoral TANs was a positive prognosticator for DSS in SCC NSCLC whereas TAN was associated with worse DSS [53].

Tumor-associated neutrophils have a dual function characterized by the N1 and N2 phenotype in a contextdependent process. N1 neutrophils have an anti-tumor phenotype through its interaction with $\mathrm{T}$ cells whereas the N2 phenotype promotes tumor growth [55]. Future studies examining the prognostic role of tumor-associated neutrophils in NSCLC should take into account the distribution of N1 and N2 phenotypes within the tumor microenvironment.

\section{T cells, CD3 positive}

Twelve studies were analysed (Supplementary Tables 1, 2, Supplementary Figure 1F) [21, 24, 52, 56-64]. Elevated CD3 $+\mathrm{T}$ cells in general compartment was associated with improved OS (HR 0.72; 0.53-0.97) (Table 1, Figure 3A). When analysed according to localisation, increased tumor $\mathrm{CD} 3+\mathrm{T}$ cells was associated with longer DSS (HR 0.64; 0.48-0.86) and suggestive for better OS (HR 0.88; 0.74-1.05) but not for RFS (HR 0.73; 0.40-1.32) (Table 1). Stromal CD3+ T cells was not associated with survival outcomes and may be suggestive of poorer DSS (HR 1.13) or DFS (HR 1.2), although results were not statistically significant. A high degree of heterogeneity was seen in studies on OS in the general compartment $\left(\mathrm{I}^{2} 70.6 \%, p=0.002\right)$. Funnel plot suggest potential publication bias with smaller studies with favourable OS in general compartment being reported (Supplementary Figure 2C).

\section{T cells, CD4 positive}

Eleven studies were analysed (Supplementary Tables 1, 2, Supplementary Figure 1G) [23, 24, 60, 64-71]. Study quality was generally good with an average score of 5.1 (Supplementary Table 1). CD4+ T cells in the general or tumor compartment had no influence on OS, RFS or DSS (Table 1, Figure 3B). In contrast, CD4+ T cells in the stroma compartment was associated with better OS (HR 0.45; 0.21-0.94) and DSS (HR 0.23; 0.06-0.95). Significant heterogeneity was seen in studies in the stromal compartment for OS $\left(\mathrm{I}^{2} 77.0 \%, p=0.013\right)$ and $\operatorname{DSS}\left(\mathrm{I}^{2} 77.4 \%, p=0.035\right)$.

\section{T cells, CD8 positive}

Twenty-three studies underwent pooled analysis (Supplementary Table 1, Supplementary Figure 1H) [23, 24, 29, 31, 32, 60-64, 66-78]. Although CD8+ T cells in the general compartment was not associated with OS (HR 0.80; 0.56-1.15) or DFS (HR 0.70; 0.48-1.02), when analysed according to tumor or stroma compartment, the prognostic value of CD8+ $\mathrm{T}$ cells could be appreciated (Table 1, Figure $3 \mathrm{C}$ ). CD8+ T cells in the tumor compartment was associated with better prognosis in terms of OS (HR 0.78; $0.66-0.93$ ) and DSS (HR 0.69; 0.50-0.96) but not for DFS (HR 0.58; 0.32-1.04) or RFS (HR 1.22; 0.82-1.83). Similarly, stromal CD8+ T cells conferred an improved OS (HR 0.77; 0.69-0.86), DFS (HR 0.73; 0.58-0.93) and DSS (HR 0.47; 0.36-0.63). Heterogeneity was low for most analytic strata. Funnel plot suggest generally no publication bias (Supplementary Figure 2D-2F).

\section{$T$ cells, regulatory}

Regulatory $\mathrm{T}$ cells (Tregs) are a subpopulation of CD4+ CD25+ T lymphocytes that inhibit anti-tumor immunity by promoting immune tolerance through direct suppressive functions on $\mathrm{T}$ cells or by secreting immunosuppressive cytokines such as IL-10 and TGF-b [79]. Tregs are purported to express and functionally depend on the transcription factor forkhead box protein P3 (FoxP3). As such many studies commonly use FoxP3 as a single marker for Tregs. Eleven studies $(n=1977$ patients) were reviewed (Supplementary Table 1 and 2, Supplementary Figure 1I). [23, 59, 60, 70, 71, 77, 80-84]. General Tregs infiltration was not associated with OS (HR $1.42 ; 0.78-2.60$ ) (Table 1, Figure 3D) whereas tumor Tregs was not associated with OS (HR 1.00; 0.75-1.34) or RFS (HR 1.53; 0.64-3.67). Stromal Tregs was not associated with OS (HR1.43; 0.69-2.94), but however was associated with worse RFS (HR 1.80; 1.34-2.43) and DFS (HR 1.69; 1.11-2.55). Most analytic strata showed low heterogeneity. studies of tumoral Treg and RFS $\left(\mathrm{I}^{2} 80.0 \%, p=0.025\right)$ and stromal OS ( $\left.\mathrm{I}^{2} 87.1 \%, p<0.001\right)$. Possible publication bias was not observed in studies of stromal Treg at the extreme HR for OS (Supplementary Figure 2G).

\section{B cells}

Apart from its role in humoral immune responses, B cells have a pro- or anti-tumorigenic function [85]. After screening, four studies were analysed for OS (Supplementary Table 1 and 2, Supplementary Figure 1J) $[38,61,86,87]$. Several studies were excluded as they had no prognostic information, insufficient information to impute HR or were the only study in an analytic stratum $[21,52,64,68,88,89]$. Results of pooled analysis found $\mathrm{B}$ cells in the tumor and stroma was associated with an improved OS with a HR for $0.65(0.42-0.99)$ and 0.74 
(0.56-0.99), respectively (Table 1, Figure 4). High heterogeneity was not seen for studies of tumor and stroma $B$ cells and OS.

\section{Cytotoxic $T$ lymphocyte antigen- 4}

CTLA-4 is not only expressed on T cells but is also found on NSCLC tumors. Three studies were assessed in full (Supplementary Table 1, Supplementary Figure 1K). Two studies had different endpoints: OS [90] and DSS (91) therefore pooled analysis was not performed. Tumor CTLA-4 overexpression was not associated with OS [90] or DSS [91]. In the third study gene expression arrays was used and CTLA-4 overexpression was associated worse OS [92].

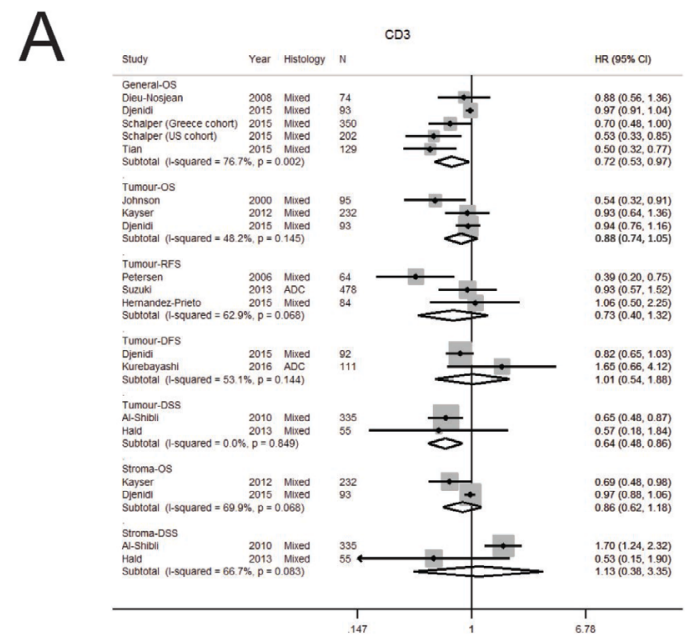

B
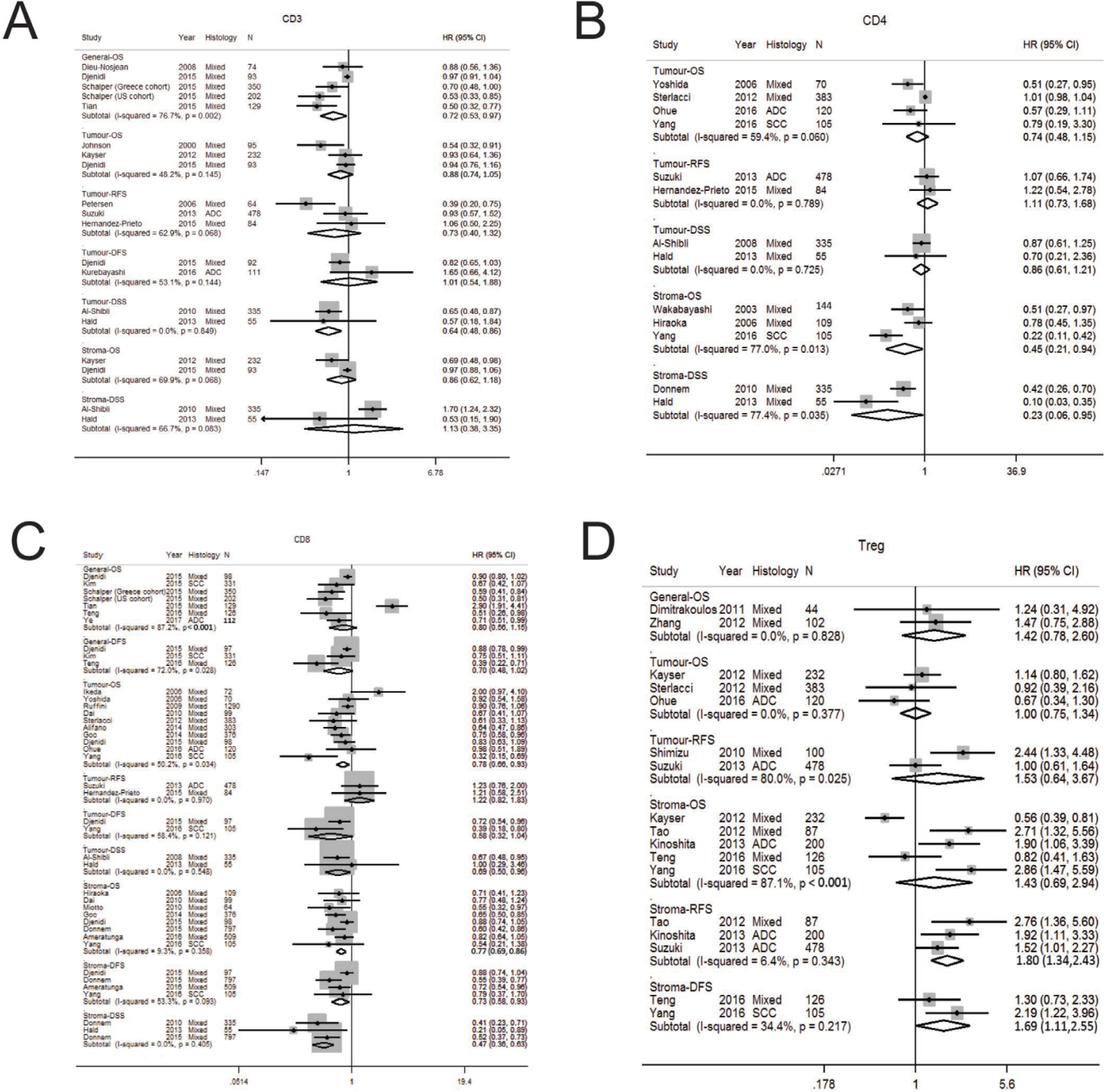

\section{Programmed death ligand-1}

The prognostic impact of PD-L1 was reported in 38 studies with 10,034 patients (Supplementary Tables 1, 2, Supplementary Figure 1L) [30, 70, 71, 75-77, 93-124]. Two additional studies were excluded $[125,126]$ as there was insufficient information to calculate the HR. Our meta-analysis found tumor PD-L1 over expression was associated with worse OS (HR 1.40; 1.20-1.69), RFS (HR 1.67; 1.22-2.29) and DFS (1.24; 1.01-1.52) (Table 1, Figure 5). Heterogeneity was high in the studies for OS $\left(\mathrm{I}^{2} 80.8 \%, p<0.001\right)$ and RFS $\left(\mathrm{I}^{2} 75.2 \%\right.$, $p<0.001)$, and moderate for DFS ( $\left.\mathrm{I}^{2} 72.9 \%, p<0.001\right)$. Publication bias was not observed and Egger's test for small-study effects was not significant for studies on

$\mathrm{D}$

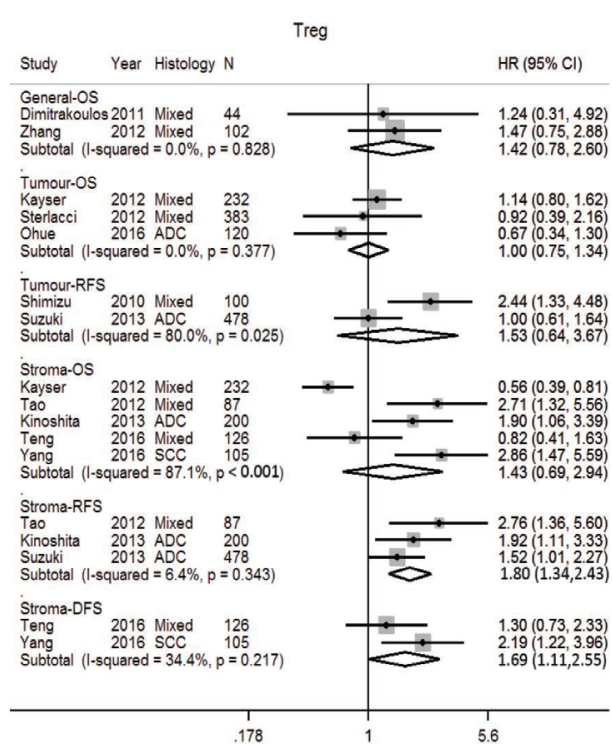

Figure 3: Forest plot of studies assessing (A) CD3+ T cells, $(\mathbf{B})$ CD4 $+\mathrm{T}$ cells, (C) CD8 $+\mathrm{T}$ cells, (D) FOXP3 + regulatory $\mathrm{T}$ cells (Treg) and survival in patients with non-small cell lung cancer (NSCLC) stratified according to localisation (in general, tumor or stroma compartment). Adenocarcinoma, ADC; confidence interval, CI; Hazard ratio, disease specific survival, DSS; hazard ratio; HR; overall survival, OS; programmed cell death-ligand 1, PD-L1; progression free survival, PFS; relapse free survival, RFS; squamous cell carcinoma, SCC. 
OS $(p=0.132)$, RFS $(p=0.663)$ and DFS $(p=0.656)$ (Supplementary Figure 2H-2J).

\section{Potential factors for heterogeneity}

We performed sensitivity analysis and subgroup analyses for studies of each immune cell to identify potential factors responsible for the heterogeneity. Sensitivity analysis was performed by excluding studies with quality score of three or less. After excluding low quality studies, there were an inadequate number of studies of M1 macrophages for metaanalysis. Mast cells, NK cells, M2 and macrophages, CD3 lymphocytes, FOXP3 + T cells and PD-L1 metaanalysis were re-analysed and prognosis were affected for two immune cell types: OS for macrophages in general was no longer associated with poor prognosis (Supplementary Figure 3C) whereas stromal regulatory $\mathrm{T}$ cells was now associated with poorer prognosis (Supplementary Figure 3F). Prognostic patterns were unchanged for the other immune cells (Supplementary Figure 3). Studies of dendritic cells, CD4 and CD8 T lymphocytes were not re-analysed as all studies had quality score of at least 4 .

Subgroup analyses were performed for immune cells with relatively large number of studies $(\geq 7$ studies). For this analysis, only studies of PD-L1 and CD8 satisfied this threshold. The subgroups analysed included ethnicity, publication year, sample size, sample type, and threshold for positive score. For CD8 cells, we found ethnicity, publication year, sample size and cut-off point were confounders for the association between tumour location (tumor, stroma) and OS (Supplementary Tables 4 and 5) but not for general location (Supplementary Table 3). For PD-L1 and OS, there was no confounding effect for the following variables: geographic location, publication year, sample size and histology (Supplementary Table 6). Ethnicity, histology and publication year may be a potential confounder for the association between PD-L1 and DFS (Supplementary Table 7) whereas histology may be a potential confounder for the association between PD-L1 and RFS (Supplementary Table 8). The role of histology as a confounder is limited by the small number of studies (two studies with mixed histology).

\section{DISCUSSION}

The immune system has been implicated to have a dual role in tumorigenesis, both suppressing tumor growth through the elimination of cancer cells and also promoting tumor growth through supply of growth and survival factors. With the rapid progress being achieved in tumor immunology and the development of cancer immunotherapy approaches, an understanding of the role of immune cells in the tumor microenvironment in NSCLC may enhance these advances in immunotherapy drug development.

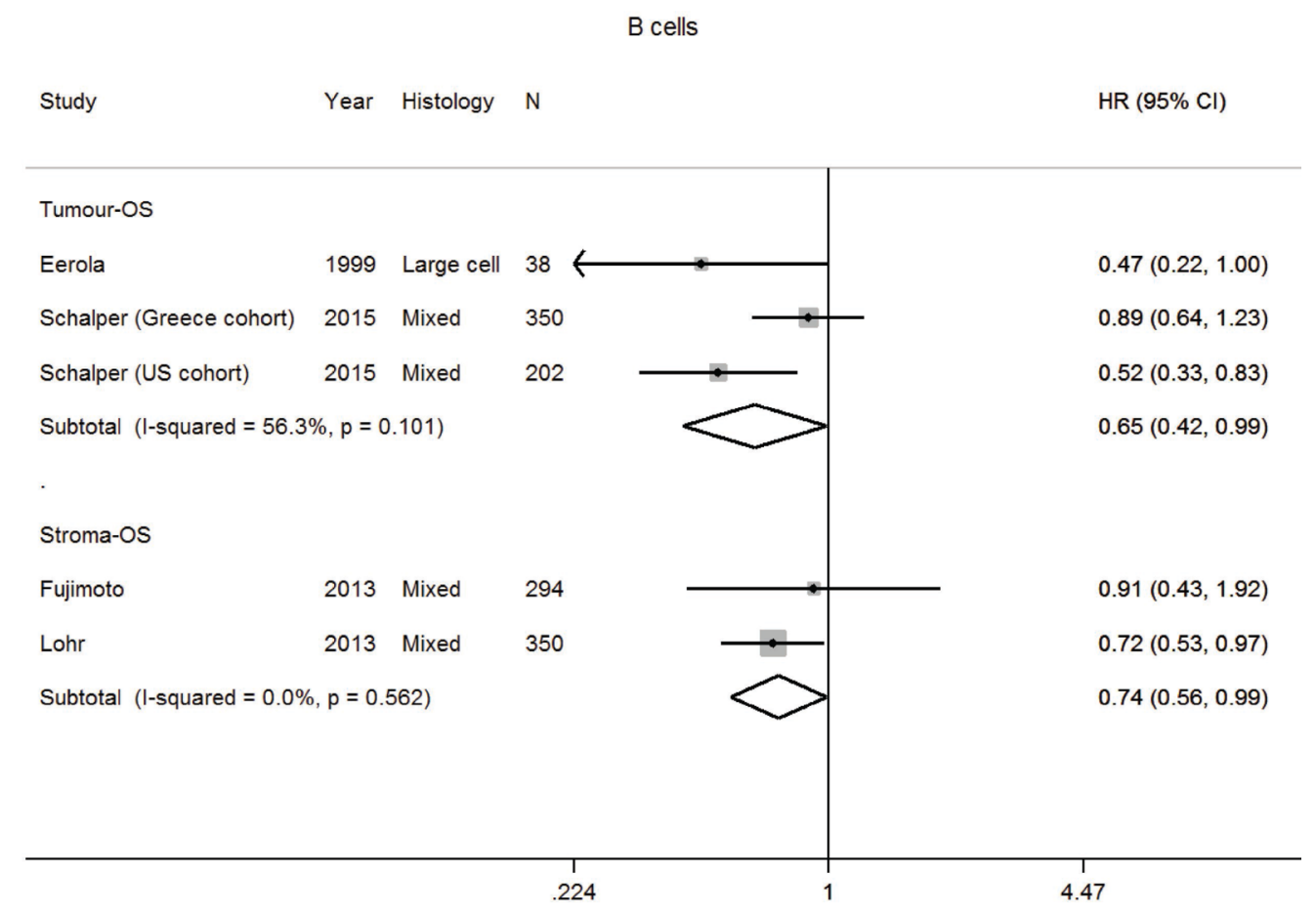

Figure 4: Forest plot of studies assessing B cells and overall survival (OS) in patients with non-small cell lung cancer (NSCLC) according to localisation in tumor or stroma compartment. Confidence interval, CI; hazard ratio, HR. 
The role of tumor-infiltrating immune cells in NSCLC is complex and its prognostic value has been studied with variable and often conflicting results. Whilst previous meta-analyses have examined the prognostic effect of specific immune cells or immune markers such as T cells [127, 128], PD-L1 [129-135] in NSCLC, the current study to our knowledge is the first meta-analysis on the prognostic impact of $\mathrm{NK}$ cells, DC, MC, and macrophages. DC, NK cells, M1 macrophages, CD3+ and CD8+ T cells were found to be associated with a favourable prognosis, whereas M2 macrophages and Tregs in the stroma were associated with a worse prognosis. These results are consistent with the role of these immune cells in anti- and pro-tumor immunity, and support the pursuit of immunotherapy as a potential therapeutic modality in NSCLC [136-140].

We also confirmed localisation influenced prognosis (Table 1). DCs, NK cells, M1 macrophages and CD8+ $\mathrm{T}$ cells in the tumor and stroma was associated with improved prognosis. TAMs localised in the tumor had a

PD-L1

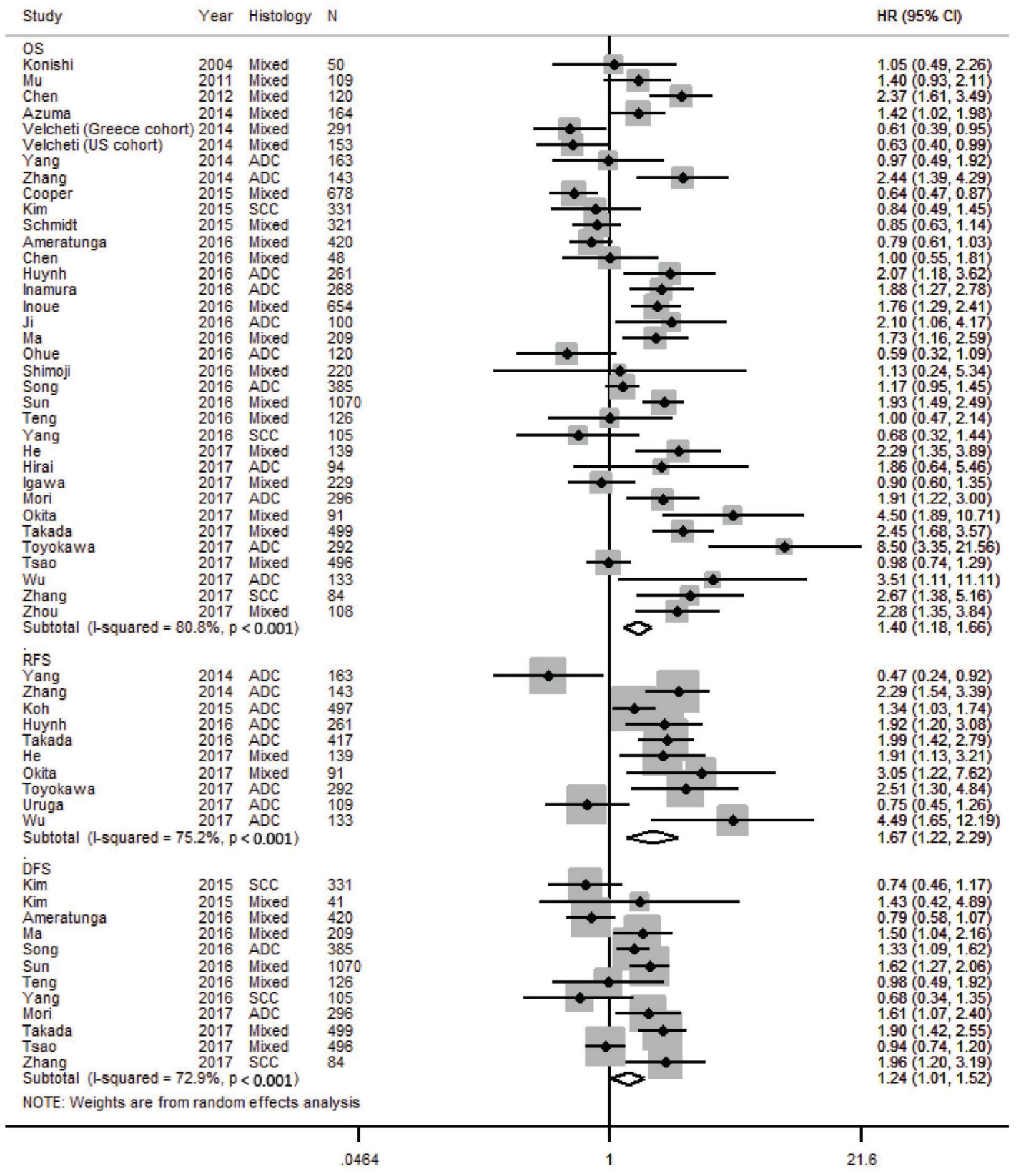

Figure 5: Forest plot of studies assessing tumor PD-L1 expression and survival outcomes in patients with non-small cell lung cancer (NSCLC). Adenocarcinoma, ADC; confidence interval, CI; Hazard ratio, disease free survival DFS; hazard ratio, HR; overall survival, OS; programmed cell death-ligand 1, PD-L1; progression free survival, PFS; relapse free survival, RFS; squamous cell carcinoma, SCC. 
better prognosis, whereas stromal TAMs were associated with a worse prognosis. Tumor M1 macrophages were associated with a better prognosis, whereas stromal M2 macrophages were associated with poorer OS, consistent with our understanding of the function of M1 and M2 macrophages [37]. These findings highlight the prognostic importance of both the immune cell phenotype (M1 or M2) as well as immune cell localisation in the tumor microenvironment, further emphasising the importance of a full understanding of the complexity of the cellular interactions within the tumor microenvironment.

The prognostic effect of immune cells has been reported in other tumors. Increased mast cells are associated with poorer prognosis in colorectal cancer (CRC) [141], malignant melanoma [142], pancreatic adenocarcinoma [143] and improved prognosis in malignant mesothelioma [144], ovarian cancer [145], and breast cancer [146]. Increased NK cells have been reported to be associated with an improved prognosis in gastric carcinoma [147, 148], CRC [149], and laryngeal cancer [150]. High CD3+ TILs have been associated with an improved OS in NSCLC [128], gastric [151], breast [152] and hepatocellular carcinoma (HCC) [153]. CD8+ $\mathrm{T}$ cells infiltration have been associated with a favourable prognosis in breast [152], ovarian [154], gastric [151], CRC [155] and HCC [153]. High FoxP3+ Tregs was associated with worse OS in cervical, renal cell carcinoma (RCC), melanoma, HCC, gastric and breast cancers and an improved OS in CRC, head and neck cancer (HNC), and oesophageal cancer whereas the DFS rate was lower in lung cancer [156]. B cell infiltration into the tumor stroma has been reported to be associated with different outcomes with an improved survival seen in breast [157], but reports for melanoma, prostate, $\mathrm{HCC}$, ovarian and HNC [158] have been inconsistent. High intratumoral neutrophil density was associated with poorer OS for HCC and intrahepatic cholangiocarcinoma, HNC, NSCLC and RCC [159]. In the same meta-analysis, the HR for OS with NSCLC was borderline, with 95\% CI of 1.0-1.35 and included one study where pre-operative chemotherapy was given [54].

A tremendous degree of heterogeneity was observed in terms of sample size (ranging from 38 to 1290 patients), geographical location of the patient population (East Asian/ non-East Asian); stage (I, I-III, I-IV), histology (adenocarcinoma or squamous cell only, or mixed histology), study methodology (sections or TMAs, antibodies used, scoring cutoffs), and survival endpoints (OS, DSS, DFS, RFS) (Table 1, Supplementary Tables 1, 2). The vast majority of studies examined mixed NSCLC histology with only a small number of studies focused adenocarcinoma or squamous cell histology only. The number of studies with East Asian varied depending on the immune cell studied. Immune cell studies published frequently from East Asia countries included PD-L1 (79\%), TAMs (66.7\%), regulatory T cells (64\%), and MC
$(60 \%)$ whereas non-East Asian studies included CD3+ T cells $(83 \%)$, NK cells $(75 \%)$, B cells $(75 \%)$ and CD8+ T cells (61\%) (Supplementary Table 1). Such differences may account for prognostic differences observed between some studies. Subgroup analyses showed ethnicity, publication year, sample size and cut-off point were confounders for OS in CD8 (Supplementary Tables 4 and 5). The studies analysed were generally moderate in quality with an average of 3.8 for NK cell studies to 5.1 for CD4+ T cells studies (Supplementary Table 1). Therefore, higher quality studies are needed to validate the results.

The choice of antibodies used may be important as different subpopulations of immune cells exist with regard to its maturation, differentiation and state of activation. This is exemplified by the various antibody clones used to detect DCs: S100 in earlier studies [26, 27], subsequently CD1a [24, 28, 30] or CD83 [29] and more in recent studies CD208 [32, 58]. The choice of antibodies used may be important as different subpopulations of dendritic cells exist in regard to its maturation, differentiation and state of activation. Mature DC has T cell co-stimulatory molecules that induce immune reactions, whereas inactivated DCs lack such T cell stimulating ability. The use of S100 IHC $\mathrm{Ab}$ is controversial as its expression in $\mathrm{DC}$ is not specific [160]. CD83 and CD208 are markers expressed in mature DCs; whereas CD1a is expressed in immature DCs [161]. As a result, the prognostic effect of DCs in the general compartment may be affected the maturation of DC: two studies using mature DC marker were associated with favorable OS $[26,32]$ whereas the study of immature DC (CD1a) was associated with worse OS [30]. Similarly, in a study examining the role of DC maturation status in patients with breast cancer, CD83 expression was prognostic for overall and relapse free survival whereas CD1a, a marker of immature DC, was not [162]. Future prognostic studies should be conducted with mature DC markers localized to the tumor center.

The number of studies analyzed according to the same tissue localization of immune cell and clinical outcome was small, further limiting our ability to draw firm conclusions (Table 1). Further studies are also required to define the prognostic role of neutrophils, CTLA-4 expression in tumor cells and PD-L1 expression in immune cells.

Tumor infiltrating lymphocytes (TILs) as a whole has been reported recently in a meta-analysis to be associated with an improved PFS [127]. However, as TILs are a heterogeneous population comprising of different $\mathrm{T}$ cell subsets, we elected to focus on the individual subsets of TILs separately due to their different functions in tumor microenvironment $[3,4]$ and thus did not analyse for the prognostic effect of tumor infiltrating lymphocytes as a group.

Our findings should be interpreted within the limitations of a meta-analysis as the data was confounded by factors such as absence of individual patient data, 
variation in study quality, HRs calculated based on the data extracted from the survival curves, differences in tissue processing, IHC staining protocols, definition of regionof-interest, scoring methodology, differences in thresholds for positivity and prognostic end points. The use of different protocols, antibodies, and scoring systems creates complexity in the interpretation of studies and applicability in clinical practice. This is especially pertinent for the detection of PD-L1, where meta-analyses studies have shown PD-L1 expression to be associated with improved outcomes in patients with NSCLC treated with immune checkpoint inhibitors [163-165]. Given the role of PD$\mathrm{L} 1$ as a prognostic biomarker and, more importantly, as a predictive marker for treatment selection, further efforts are clearly required to standardise the detection of PDL1 expression and also to determine factors of variability between IHC assays [166, 167]. Apart from to PD-L1, international efforts are also underway to standardise the assessment of tumor-infiltrating lymphocytes in NSCLC as well as other solid tumors $[168,169]$.

Future studies should examine the role of immune cells as a new prognostic factor in staging. Similar to developments were made in CRC [170, 171], while approaches to integrate tumor-infiltrating lymphocytes into NSCLC staging are being pursued [172]. In addition to incorporating tumor-infiltrating lymphocytes, further prospective studies using multi-immune cell panels/ multiparametric IHC are also desirable to determine the most promising combination of immune cells as a prognostic marker in NSCLC. Recent studies of molecular tumor profiling with immune cell phenotyping $[173,174]$ has improved our understanding of the complex relationship between tumor and the tumor microenvironment and may lead to improvements in therapeutic outcomes in NSCLC.

\section{CONCLUSIONS}

Our findings suggest DC, NK cells, M1 macrophages, $\mathrm{CD} 8+\mathrm{T}$ cells, and $\mathrm{B}$ cells in the tumor and stroma are associated with an improved prognosis and stromal M2 macrophages, regulatory $\mathrm{T}$ cells and PD-L1 overexpression are associated with poorer prognosis in NSCLC. Future research should focus on the standardisation of immune cell detection, use of multi-immune cell panels as a prognostic biomarker, and incorporating immune cells into prognostic models.

\section{ACKNOWLEDGMENTS}

This study was supported by the National Research Foundation Singapore and the Singapore Ministry of Education under its Research Centres of Excellence initiative.

\section{CONFLICTS OF INTEREST}

The authors declare no conflicts of interest.

\section{REFERENCES}

1. Torre LA, Bray F, Siegel RL, Ferlay J, Lortet-Tieulent J, Jemal A. Global cancer statistics, 2012. CA Cancer J Clin. 2015; 65:87-108.

2. Hanahan D, Weinberg RA. Hallmarks of cancer: the next generation. Cell. 2011; 144:646-74.

3. Hanahan D, Coussens LM. Accessories to the crime: functions of cells recruited to the tumor microenvironment. Cancer Cell. 2012; 21:309-22.

4. Fridman WH, Pagès F, Sautès-Fridman $C$, Galon J. The immune contexture in human tumours: impact on clinical outcome. Nat Rev Cancer. 2012; 12:298-306.

5. Sundar R, Soong R, Cho BC, Brahmer JR, Soo RA. Immunotherapy in the treatment of non-small cell lung cancer. Lung Cancer. 2014; 85:101-09.

6. Soo RA, Stone EC, Cummings KM, Jett JR, Field JK, Groen HJ, Mulshine JL, Yatabe Y, Bubendorf L, Dacic S, Rami-Porta R, Detterbeck FC, Lim E, et al. Scientific Advances in Thoracic Oncology 2016. J Thorac Oncol. 2017; 12:1183-209.

7. Pakkala S, Ramalingam SS. Adjuvant therapy for nonsmall cell lung cancer: recent advances and future perspectives. Curr Opin Oncol. 2016; 28:150-58.

8. Moher D, Liberati A, Tetzlaff J, Altman DG, and PRISMA Group. Preferred reporting items for systematic reviews and meta-analyses: the PRISMA statement. PLoS Med. 2009; 6:e1000097.

9. McShane LM, Altman DG, Sauerbrei W, Taube SE, Gion M, Clark GM, and Statistics Subcommittee of the NCIEORTC Working Group on Cancer Diagnostics. REporting recommendations for tumour MARKer prognostic studies (REMARK). Br J Cancer. 2005; 93:387-91.

10. Hayes DF, Bast RC, Desch CE, Fritsche H Jr, Kemeny NE, Jessup JM, Locker GY, Macdonald JS, Mennel RG, Norton L, Ravdin P, Taube S, Winn RJ. Tumor marker utility grading system: a framework to evaluate clinical utility of tumor markers. J Natl Cancer Inst. 1996; 88:1456-66.

11. Parmar MK, Torri V, Stewart L. Extracting summary statistics to perform meta-analyses of the published literature for survival endpoints. Stat Med. 1998; 17:2815-34.

12. DerSimonian R, Laird N. Meta-analysis in clinical trials. Control Clin Trials. 1986; 7:177-88.

13. Higgins JP, Thompson SG, Deeks JJ, Altman DG. Measuring inconsistency in meta-analyses. BMJ. 2003; 327:557-60.

14. Dalton DK, Noelle RJ. The roles of mast cells in anticancer immunity. Cancer Immunol Immunother. 2012; 61:1511-20. 
15. Tomita M, Matsuzaki Y, Onitsuka T. Correlation between mast cells and survival rates in patients with pulmonary adenocarcinoma. Lung Cancer. 1999; 26:103-08.

16. Takanami I, Takeuchi K, Naruke M. Mast cell density is associated with angiogenesis and poor prognosis in pulmonary adenocarcinoma. Cancer. 2000; 88:2686-92.

17. Imada A, Shijubo N, Kojima H, Abe S. Mast cells correlate with angiogenesis and poor outcome in stage I lung adenocarcinoma. Eur Respir J. 2000; 15:1087-93.

18. Kojima H, Shijubo N, Abe S. Thymidine phosphorylase and vascular endothelial growth factor in patients with Stage I lung adenocarcinoma. Cancer. 2002; 94:1083-93.

19. Nagata M, Shijubo N, Walls AF, Ichimiya S, Abe S, Sato N. Chymase-positive mast cells in small sized adenocarcinoma of the lung. Virchows Arch. 2003; 443:565-73.

20. Kojima H, Shijubo N, Yamada G, Ichimiya S, Abe S, Satoh M, Sato N. Clinical significance of vascular endothelial growth factor-C and vascular endothelial growth factor receptor 3 in patients with T1 lung adenocarcinoma. Cancer. 2005; 104:1668-77.

21. Welsh TJ, Green RH, Richardson D, Waller DA, O'Byrne KJ, Bradding P. Macrophage and mast-cell invasion of tumor cell islets confers a marked survival advantage in non-small-cell lung cancer. J Clin Oncol. 2005; 23:8959-67.

22. Al-Shibli K, Al-Saad S, Andersen S, Donnem T, Bremnes RM, Busund LT. The prognostic value of intraepithelial and stromal CD3-, CD117- and CD138positive cells in non-small cell lung carcinoma. APMIS. 2010; 118:371-82.

23. Sterlacci W, Wolf D, Savic S, Hilbe W, Schmid T, Jamnig H, Fiegl M, Tzankov A. High transforming growth factor $\beta$ expression represents an important prognostic parameter for surgically resected non-small cell lung cancer. Hum Pathol. 2012; 43:339-49.

24. Hald SM, Bremnes RM, Al-Shibli K, Al-Saad S, Andersen S, Stenvold H, Busund LT, Donnem T. CD4/ CD8 co-expression shows independent prognostic impact in resected non-small cell lung cancer patients treated with adjuvant radiotherapy. Lung Cancer. 2013; 80:209-15.

25. Mellman I. Dendritic cells: master regulators of the immune response. Cancer Immunol Res. 2013; 1:145-49.

26. Furukawa T, Watanabe S, Kodama T, Sato Y, Shimosato Y, Suemasu K. T-zone histiocytes in adenocarcinoma of the lung in relation to postoperative prognosis. Cancer. 1985; 56:2651-56.

27. Inoshima $\mathrm{N}$, Nakanishi $\mathrm{Y}$, Minami $\mathrm{T}$, Izumi $\mathrm{M}$, Takayama K, Yoshino I, Hara N. The influence of dendritic cell infiltration and vascular endothelial growth factor expression on the prognosis of non-small cell lung cancer. Clin Cancer Res. 2002; 8:3480-86.

28. Al-Shibli K, Al-Saad S, Donnem T, Persson M, Bremnes RM, Busund LT. The prognostic value of intraepithelial and stromal innate immune system cells in non-small cell lung carcinoma. Histopathology. 2009; 55:301-12.

29. Dai F, Liu L, Che G, Yu N, Pu Q, Zhang S, Ma J, Ma L, You Z. The number and microlocalization of tumorassociated immune cells are associated with patient's survival time in non-small cell lung cancer. BMC Cancer. 2010; 10:220.

30. Mu CY, Huang JA, Chen Y, Chen C, Zhang XG. High expression of PD-L1 in lung cancer may contribute to poor prognosis and tumor cells immune escape through suppressing tumor infiltrating dendritic cells maturation. Med Oncol. 2011; 28:682-88.

31. Alifano M, Mansuet-Lupo A, Lococo F, Roche N, Bobbio A, Canny E, Schussler O, Dermine H, Régnard JF, Burroni B, Goc J, Biton J, Ouakrim H, et al. Systemic inflammation, nutritional status and tumor immune microenvironment determine outcome of resected non-small cell lung cancer. PLoS One. 2014; 9:e106914.

32. Goc J, Germain C, Vo-Bourgais TK, Lupo A, Klein C, Knockaert S, de Chaisemartin L, Ouakrim H, Becht E, Alifano M, Validire P, Remark R, Hammond SA, et al. Dendritic cells in tumor-associated tertiary lymphoid structures signal a Th1 cytotoxic immune contexture and license the positive prognostic value of infiltrating CD8+ T cells. Cancer Res. 2014; 74:705-15.

33. Vivier E, Tomasello E, Baratin M, Walzer T, Ugolini S. Functions of natural killer cells. Nat Immunol. 2008; 9:503-10.

34. Takanami I, Takeuchi K, Giga M. The prognostic value of natural killer cell infiltration in resected pulmonary adenocarcinoma. J Thorac Cardiovasc Surg. 2001; 121:1058-63.

35. Villegas FR, Coca S, Villarrubia VG, Jiménez R, Chillón MJ, Jareño J, Zuil M, Callol L. Prognostic significance of tumor infiltrating natural killer cells subset CD57 in patients with squamous cell lung cancer. Lung Cancer. 2002; 35:23-28.

36. Platonova S, Cherfils-Vicini J, Damotte D, Crozet L, Vieillard V, Validire P, André P, Dieu-Nosjean MC, Alifano M, Régnard JF, Fridman WH, Sautès-Fridman C, Cremer I. Profound coordinated alterations of intratumoral NK cell phenotype and function in lung carcinoma. Cancer Res. 2011; 71:5412-22.

37. Mantovani A, Marchesi F, Malesci A, Laghi L, Allavena P. Tumour-associated macrophages as treatment targets in oncology. Nat Rev Clin Oncol. 2017; 14:399-416.

38. Eerola AK, Soini Y, Pääkkö P. Tumour infiltrating lymphocytes in relation to tumour angiogenesis, apoptosis and prognosis in patients with large cell lung carcinoma. Lung Cancer. 1999; 26:73-83.

39. Takanami I, Takeuchi K, Kodaira S. Tumor-associated macrophage infiltration in pulmonary adenocarcinoma: association with angiogenesis and poor prognosis. Oncology. 1999; 57:138-42. 
40. Chen JJ, Yao PL, Yuan A, Hong TM, Shun CT, Kuo ML, Lee YC, Yang PC. Up-regulation of tumor interleukin-8 expression by infiltrating macrophages: its correlation with tumor angiogenesis and patient survival in non-small cell lung cancer. Clin Cancer Res. 2003; 9:729-37.

41. Kim DW, Min HS, Lee KH, Kim YJ, Oh DY, Jeon YK, Lee SH, Im SA, Chung DH, Kim YT, Kim TY, Bang YJ, Sung SW, et al. High tumour islet macrophage infiltration correlates with improved patient survival but not with EGFR mutations, gene copy number or protein expression in resected non-small cell lung cancer. Br J Cancer. 2008; 98:1118-24

42. Ohri CM, Shikotra A, Green RH, Waller DA, Bradding P. Macrophages within NSCLC tumour islets are predominantly of a cytotoxic M1 phenotype associated with extended survival. Eur Respir J. 2009; 33:118-26.

43. Ohtaki Y, Ishii G, Nagai K, Ashimine S, Kuwata T, Hishida T, Nishimura M, Yoshida J, Takeyoshi I, Ochiai A. Stromal macrophage expressing CD204 is associated with tumor aggressiveness in lung adenocarcinoma. J Thorac Oncol. 2010; 5:1507-15.

44. Ma J, Liu L, Che G, Yu N, Dai F, You Z. The M1 form of tumor-associated macrophages in non-small cell lung cancer is positively associated with survival time. BMC Cancer. 2010; 10:112.

45. Zhang BC, Gao J, Wang J, Rao ZG, Wang BC, Gao JF. Tumor-associated macrophages infiltration is associated with peritumoral lymphangiogenesis and poor prognosis in lung adenocarcinoma. Med Oncol. 2011; 28:1447-52.

46. Zhang B, Yao G, Zhang Y, Gao J, Yang B, Rao Z, Gao J. M2-polarized tumor-associated macrophages are associated with poor prognoses resulting from accelerated lymphangiogenesis in lung adenocarcinoma. Clinics (São Paulo). 2011; 66:1879-86.

47. Hirayama S, Ishii G, Nagai $\mathrm{K}$, Ono $\mathrm{S}$, Kojima $\mathrm{M}$, Yamauchi C, Aokage K, Hishida T, Yoshida J, Suzuki K, Ochiai A. Prognostic impact of CD204-positive macrophages in lung squamous cell carcinoma: possible contribution of Cd204-positive macrophages to the tumor-promoting microenvironment. J Thorac Oncol. 2012; 7:1790-97.

48. Ito M, Ishii G, Nagai K, Maeda R, Nakano Y, Ochiai A. Prognostic impact of cancer-associated stromal cells in patients with stage I lung adenocarcinoma. Chest. 2012; 142:151-58.

49. Carus A, Ladekarl M, Hager H, Pilegaard H, Nielsen PS, Donskov F. Tumor-associated neutrophils and macrophages in non-small cell lung cancer: no immediate impact on patient outcome. Lung Cancer. 2013; 81:130-37.

50. Pei BX, Sun BS, Zhang ZF, Wang AL, Ren P. Interstitial tumor-associated macrophages combined with tumorderived colony-stimulating factor- 1 and interleukin-6, a novel prognostic biomarker in non-small cell lung cancer. J Thorac Cardiovasc Surg. 2014; 148:1208-1216.e2.
51. Treffers LW, Hiemstra IH, Kuijpers TW, van den Berg TK, Matlung HL. Neutrophils in cancer. Immunol Rev. 2016; 273:312-28.

52. Kurebayashi Y, Emoto K, Hayashi Y, Kamiyama I, Ohtsuka T, Asamura H, Sakamoto M. Comprehensive Immune Profiling of Lung Adenocarcinomas Reveals Four Immunosubtypes with Plasma Cell Subtype a Negative Indicator. Cancer Immunol Res. 2016; 4:234-47.

53. Rakaee M, Busund LT, Paulsen EE, Richardsen E, Al-Saad S, Andersen S, Donnem T, Bremnes RM, Kilvaer TK. Prognostic effect of intratumoral neutrophils across histological subtypes of non-small cell lung cancer. Oncotarget. 2016; 7:72184-96. https://doi.org/10.18632/ oncotarget. 12360 .

54. Ilie M, Hofman V, Ortholan C, Bonnetaud C, Coëlle C, Mouroux J, Hofman P. Predictive clinical outcome of the intratumoral CD66b-positive neutrophil-to-CD8-positive T-cell ratio in patients with resectable nonsmall cell lung cancer. Cancer. 2012; 118:1726-37.

55. Fridlender ZG, Sun J, Kim S, Kapoor V, Cheng G, Ling L, Worthen GS, Albelda SM. Polarization of tumor-associated neutrophil phenotype by TGF-beta: "N1" versus "N2" TAN. Cancer Cell. 2009; 16:183-94.

56. Johnson SK, Kerr KM, Chapman AD, Kennedy MM, King G, Cockburn JS, Jeffrey RR. Immune cell infiltrates and prognosis in primary carcinoma of the lung. Lung Cancer. 2000; 27:27-35.

57. Petersen RP, Campa MJ, Sperlazza J, Conlon D, Joshi MB, Harpole DH Jr, Patz EF Jr. Tumor infiltrating Foxp3+ regulatory T-cells are associated with recurrence in pathologic stage I NSCLC patients. Cancer. 2006; 107:2866-72.

58. Dieu-Nosjean MC, Antoine M, Danel C, Heudes D, Wislez M, Poulot V, Rabbe N, Laurans L, Tartour E, de Chaisemartin L, Lebecque S, Fridman WH, Cadranel J. Long-term survival for patients with non-small-cell lung cancer with intratumoral lymphoid structures. J Clin Oncol. 2008; 26:4410-17.

59. Kayser G, Schulte-Uentrop L, Sienel W, Werner M, Fisch P, Passlick B, Zur Hausen A, Stremmel C. Stromal CD4/CD25 positive T-cells are a strong and independent prognostic factor in non-small cell lung cancer patients, especially with adenocarcinomas. Lung Cancer. 2012; 76:445-51.

60. Suzuki K, Kadota K, Sima CS, Nitadori J, Rusch VW, Travis WD, Sadelain M, Adusumilli PS. Clinical impact of immune microenvironment in stage I lung adenocarcinoma: tumor interleukin-12 receptor $\beta 2$ (IL-12R $\beta 2$ ), IL-7R, and stromal FoxP3/CD3 ratio are independent predictors of recurrence. J Clin Oncol. 2013; 31:490-98.

61. Schalper KA, Brown J, Carvajal-Hausdorf D, McLaughlin J, Velcheti V, Syrigos KN, Herbst RS, Rimm DL. Objective measurement and clinical significance of TILs in non-small cell lung cancer. J Natl Cancer Inst. 2015; 107:dju435. 
62. Tian C, Lu S, Fan Q, Zhang W, Jiao S, Zhao X, Wu Z, Sun L, Wang L. Prognostic significance of tumor-infiltrating $\mathrm{CD}^{+}$or $\mathrm{CD}^{+} \mathrm{T}$ lymphocytes and interleukin- 2 expression in radically resected non-small cell lung cancer. Chin Med J (Engl). 2015; 128:105-10.

63. Djenidi F, Adam J, Goubar A, Durgeau A, Meurice G, de Montpréville V, Validire P, Besse B, Mami-Chouaib F. CD8+CD103+ tumor-infiltrating lymphocytes are tumorspecific tissue-resident memory $\mathrm{T}$ cells and a prognostic factor for survival in lung cancer patients. J Immunol. 2015; 194:3475-86.

64. Hernández-Prieto S, Romera A, Ferrer M, Subiza JL, LópezAsenjo JA, Jarabo JR, Gómez AM, Molina EM, Puente J, González-Larriba JL, Hernando F, Pérez-Villamil B, DíazRubio E, Sanz-Ortega J. A 50-gene signature is a novel scoring system for tumor-infiltrating immune cells with strong correlation with clinical outcome of stage I/II nonsmall cell lung cancer. Clin Transl Oncol. 2015; 17:330-38.

65. Wakabayashi O, Yamazaki K, Oizumi S, Hommura F, Kinoshita I, Ogura S, Dosaka-Akita H, Nishimura M. CD4+ $\mathrm{T}$ cells in cancer stroma, not CD8+ T cells in cancer cell nests, are associated with favorable prognosis in human non-small cell lung cancers. Cancer Sci. 2003; 94:1003-09.

66. Hiraoka K, Miyamoto M, Cho Y, Suzuoki M, Oshikiri T, Nakakubo Y, Itoh T, Ohbuchi T, Kondo S, Katoh H. Concurrent infiltration by CD8 $+\mathrm{T}$ cells and CD4+ T cells is a favourable prognostic factor in non-small-cell lung carcinoma. Br J Cancer. 2006; 94:275-80.

67. Yoshida N, Abe H, Ohkuri T, Wakita D, Sato M, Noguchi D, Miyamoto M, Morikawa T, Kondo S, Ikeda H, Nishimura T. Expression of the MAGE-A4 and NY-ESO-1 cancer-testis antigens and $\mathrm{T}$ cell infiltration in non-small cell lung carcinoma and their prognostic significance. Int $\mathrm{J}$ Oncol. 2006; 28:1089-98.

68. Al-Shibli KI, Donnem T, Al-Saad S, Persson M, Bremnes RM, Busund LT. Prognostic effect of epithelial and stromal lymphocyte infiltration in non-small cell lung cancer. Clin Cancer Res. 2008; 14:5220-27.

69. Donnem T, Al-Shibli K, Andersen S, Al-Saad S, Busund LT, Bremnes RM. Combination of low vascular endothelial growth factor A (VEGF-A)/VEGF receptor 2 expression and high lymphocyte infiltration is a strong and independent favorable prognostic factor in patients with nonsmall cell lung cancer. Cancer. 2010; 116:4318-25.

70. Yang CY, Lin MW, Chang YL, Wu CT, Yang PC. Programmed cell death-ligand 1 expression is associated with a favourable immune microenvironment and better overall survival in stage I pulmonary squamous cell carcinoma. Eur J Cancer. 2016; 57:91-103.

71. Ohue Y, Kurose K, Nozawa R, Isobe M, Nishio Y, Tanaka T, Doki Y, Hori T, Fukuoka J, Oka M, Nakayama E. Survival of Lung Adenocarcinoma Patients Predicted from Expression of PD-L1, Galectin-9, and XAGE1 (GAGED2a) on Tumor Cells and Tumor-Infiltrating T Cells. Cancer Immunol Res. 2016; 4:1049-60.
72. Ruffini E, Asioli S, Filosso PL, Lyberis P, Bruna MC, Macrì L, Daniele L, Oliaro A. Clinical significance of tumor-infiltrating lymphocytes in lung neoplasms. Ann Thorac Surg. 2009; 87:365-71.

73. Miotto D, Lo Cascio N, Stendardo M, Querzoli P, Pedriali M, De Rosa E, Fabbri LM, Mapp CE, Boschetto P. CD8+ T cells expressing IL-10 are associated with a favourable prognosis in lung cancer. Lung Cancer. 2010; 69:355-60.

74. Donnem T, Hald SM, Paulsen EE, Richardsen E, Al-Saad S, Kilvaer TK, Brustugun OT, Helland A, Lund-Iversen M, Poehl M, Olsen KE, Ditzel HJ, Hansen O, et al. Stromal CD8+ T-cell Density-A Promising Supplement to TNM Staging in Non-Small Cell Lung Cancer. Clin Cancer Res. 2015; 21:2635-43.

75. Kim MY, Koh J, Kim S, Go H, Jeon YK, Chung DH. Clinicopathological analysis of PD-L1 and PD-L2 expression in pulmonary squamous cell carcinoma: comparison with tumor-infiltrating T cells and the status of oncogenic drivers. Lung Cancer. 2015; 88:24-33.

76. Ameratunga M, Asadi K, Lin X, Walkiewicz M, Murone C, Knight S, Mitchell P, Boutros P, John T. PD-L1 and Tumor Infiltrating Lymphocytes as Prognostic Markers in Resected NSCLC. PLoS One. 2016; 11:e0153954.

77. Teng F, Meng X, Wang X, Yuan J, Liu S, Mu D, Zhu H, Kong L, Yu J. Expressions of CD8+TILs, PD-L1 and Foxp3+TILs in stage I NSCLC guiding adjuvant chemotherapy decisions. Oncotarget. 2016; 7:64318-29. https://doi.org/10.18632/oncotarget.11793.

78. Ye SL, Li XY, Zhao K, Feng T. High expression of CD8 predicts favorable prognosis in patients with lung adenocarcinoma: A cohort study. Medicine (Baltimore). 2017; 96:e6472.

79. Zou W. Regulatory $\mathrm{T}$ cells, tumour immunity and immunotherapy. Nat Rev Immunol. 2006; 6:295-307.

80. Shimizu K, Nakata M, Hirami Y, Yukawa T, Maeda A, Tanemoto K. Tumor-infiltrating Foxp3+ regulatory T cells are correlated with cyclooxygenase- 2 expression and are associated with recurrence in resected non-small cell lung cancer. J Thorac Oncol. 2010; 5:585-90.

81. Dimitrakopoulos FI, Papadaki H, Antonacopoulou AG, Kottorou A, Gotsis AD, Scopa C, Kalofonos HP, Mouzaki A. Association of FOXP3 expression with nonsmall cell lung cancer. Anticancer Res. 2011; 31:1677-83.

82. Tao H, Mimura Y, Aoe K, Kobayashi S, Yamamoto H, Matsuda E, Okabe K, Matsumoto T, Sugi K, Ueoka H. Prognostic potential of FOXP3 expression in non-small cell lung cancer cells combined with tumor-infiltrating regulatory T cells. Lung Cancer. 2012; 75:95-101.

83. Zhang GQ, Han F, Fang XZ, Ma XM. CD4+, IL17 and Foxp3 expression in different pTNM stages of operable non-small cell lung cancer and effects on disease prognosis. Asian Pac J Cancer Prev. 2012; 13:3955-60.

84. Kinoshita T, Ishii G, Hiraoka N, Hirayama S, Yamauchi C, Aokage K, Hishida T, Yoshida J, Nagai K, Ochiai A. 
Forkhead box P3 regulatory T cells coexisting with cancer associated fibroblasts are correlated with a poor outcome in lung adenocarcinoma. Cancer Sci. 2013; 104:409-15.

85. Tsou P, Katayama H, Ostrin EJ, Hanash SM. The Emerging Role of B Cells in Tumor Immunity. Cancer Res. 2016; 76:5597-601.

86. Fujimoto M, Yoshizawa A, Sumiyoshi S, Sonobe M, Kobayashi M, Koyanagi I, Aini W, Tsuruyama T, Date H, Haga H. Stromal plasma cells expressing immunoglobulin G4 subclass in non-small cell lung cancer. Hum Pathol. 2013; 44:1569-76.

87. Lohr M, Edlund K, Botling J, Hammad S, Hellwig B, Othman A, Berglund A, Lambe M, Holmberg L, Ekman S, Bergqvist M, Pontén F, Cadenas C, et al. The prognostic relevance of tumour-infiltrating plasma cells and immunoglobulin kappa $\mathrm{C}$ indicates an important role of the humoral immune response in non-small cell lung cancer. Cancer Lett. 2013; 333:222-28.

88. Pelletier MP, Edwardes MD, Michel RP, Halwani F, Morin JE. Prognostic markers in resectable non-small cell lung cancer: a multivariate analysis. Can J Surg. 2001; 44:180-88.

89. Germain C, Gnjatic S, Tamzalit F, Knockaert S, Remark R, Goc J, Lepelley A, Becht E, Katsahian S, Bizouard G, Validire P, Damotte D, Alifano M, et al. Presence of B cells in tertiary lymphoid structures is associated with a protective immunity in patients with lung cancer. Am J Respir Crit Care Med. 2014; 189:832-44.

90. Salvi S, Fontana V, Boccardo S, Merlo DF, Margallo E, Laurent S, Morabito A, Rijavec E, Dal Bello MG, Mora M, Ratto GB, Grossi F, Truini M, Pistillo MP. Evaluation of CTLA-4 expression and relevance as a novel prognostic factor in patients with non-small cell lung cancer. Cancer Immunol Immunother. 2012; 61:1463-72.

91. Paulsen EE, Kilvaer TK, Rakaee M, Richardsen E, Hald SM, Andersen S, Busund LT, Bremnes RM, Donnem T. CTLA-4 expression in the non-small cell lung cancer patient tumor microenvironment: diverging prognostic impact in primary tumors and lymph node metastases. Cancer Immunol Immunother. 2017; 66:1449-61.

92. Deng L, Gyorffy B, Na F, Chen B, Lan J, Xue J, Zhou L, $\mathrm{Lu}$ Y. Association of PDCD1 and CTLA-4 Gene Expression with Clinicopathological Factors and Survival in NonSmall-Cell Lung Cancer: Results from a Large and Pooled Microarray Database. J Thorac Oncol. 2015; 10:1020-26.

93. Konishi J, Yamazaki K, Azuma M, Kinoshita I, DosakaAkita H, Nishimura M. B7-H1 expression on non-small cell lung cancer cells and its relationship with tumor-infiltrating lymphocytes and their PD-1 expression. Clin Cancer Res. 2004; 10:5094-100.

94. Chen YB, Mu CY, Huang JA. Clinical significance of programmed death-1 ligand-1 expression in patients with non-small cell lung cancer: a 5-year-follow-up study. Tumori. 2012; 98:751-55.
95. Azuma K, Ota K, Kawahara A, Hattori S, Iwama E, Harada T, Matsumoto K, Takayama K, Takamori S, Kage M, Hoshino T, Nakanishi Y, Okamoto I. Association of PD-L1 overexpression with activating EGFR mutations in surgically resected nonsmall-cell lung cancer. Ann Oncol. 2014; 25:1935-40.

96. Velcheti V, Schalper KA, Carvajal DE, Anagnostou VK, Syrigos KN, Sznol M, Herbst RS, Gettinger SN, Chen L, Rimm DL. Programmed death ligand-1 expression in nonsmall cell lung cancer. Lab Invest. 2014; 94:107-16.

97. Yang CY, Lin MW, Chang YL, Wu CT, Yang PC. Programmed cell death-ligand 1 expression in surgically resected stage I pulmonary adenocarcinoma and its correlation with driver mutations and clinical outcomes. Eur J Cancer. 2014; 50:1361-69.

98. Zhang Y, Wang L, Li Y, Pan Y, Wang R, Hu H, Li H, Luo X, Ye T, Sun Y, Chen H. Protein expression of programmed death 1 ligand 1 and ligand 2 independently predict poor prognosis in surgically resected lung adenocarcinoma. OncoTargets Ther. 2014; 7:567-73.

99. Koh J, Go H, Keam B, Kim MY, Nam SJ, Kim TM, Lee SH, Min HS, Kim YT, Kim DW, Jeon YK, Chung DH. Clinicopathologic analysis of programmed cell death-1 and programmed cell death-ligand 1 and 2 expressions in pulmonary adenocarcinoma: comparison with histology and driver oncogenic alteration status. Mod Pathol. 2015; 28:1154-66.

100. Kim S, Kim MY, Koh J, Go H, Lee DS, Jeon YK, Chung DH. Programmed death-1 ligand 1 and 2 are highly expressed in pleomorphic carcinomas of the lung: comparison of sarcomatous and carcinomatous areas. Eur J Cancer. 2015; 51:2698-707.

101. Cooper WA, Tran T, Vilain RE, Madore J, Selinger CI, Kohonen-Corish M, Yip P, Yu B, O'Toole SA, McCaughan BC, Yearley JH, Horvath LG, Kao S, et al. PD-L1 expression is a favorable prognostic factor in early stage non-small cell carcinoma. Lung Cancer. 2015; 89:181-88.

102. Schmidt LH, Kümmel A, Görlich D, Mohr M, Bröckling S, Mikesch JH, Grünewald I, Marra A, Schultheis AM, Wardelmann E, Müller-Tidow C, Spieker T, Schliemann C, et al. PD-1 and PD-L1 Expression in NSCLC Indicate a Favorable Prognosis in Defined Subgroups. PLoS One. 2015; 10:e0136023.

103. Tsao MS, Le Teuff G, Shepherd FA, Landais C, Hainaut P, Filipits M, Pirker R, Le Chevalier T, Graziano S, Kratze R, Soria JC, Pignon JP, Seymour L, Brambilla E. PD-L1 protein expression assessed by immunohistochemistry is neither prognostic nor predictive of benefit from adjuvant chemotherapy in resected non-small cell lung cancer. Ann Oncol. 2017; 28:882-89.

104. Mori S, Motoi N, Ninomiya H, Matsuura Y, Nakao M, Mun M, Okumura S, Nishio M, Morikawa T, Ishikawa Y. High expression of programmed cell death 1 ligand 1 in lung adenocarcinoma is a poor prognostic factor particularly 
in smokers and wild-type epidermal growth-factor receptor cases. Pathol Int. 2017; 67:37-44.

105. Ma Y, Zhang P, An G, Zhang X, Zhang L, Si J, Zhang J, Yang Y. Induction of Patient-Derived Xenograft Formation and Clinical Significance of Programmed Cell Death Ligand 1 (PD-L1) in Lung Cancer Patients. Med Sci Monit. 2016; 22:4017-25.

106. Inamura K, Yokouchi Y, Sakakibara R, Kobayashi M, Subat S, Ninomiya H, Nagano H, Nomura K, Okumura S, Ishikawa Y. Relationship of tumor PD-L1 expression with EGFR wild-type status and poor prognosis in lung adenocarcinoma. Jpn J Clin Oncol. 2016; 46:935-41.

107. Sun JM, Zhou W, Choi YL, Choi SJ, Kim SE, Wang Z, Dolled-Filhart M, Emancipator K, Wu D, Weiner R, Frisman D, Kim HK, Choi YS, et al. Prognostic Significance of PD-L1 in Patients with Non-Small Cell Lung Cancer: A Large Cohort Study of Surgically Resected Cases. J Thorac Oncol. 2016; 11:1003-11.

108. Chen Z, Mei J, Liu L, Wang G, Li Z, Hou J, Zhang Q, You Z, Zhang L. PD-L1 expression is associated with advanced nonsmall cell lung cancer. Oncol Lett. 2016; 12:921-27.

109. Huynh TG, Morales-Oyarvide V, Campo MJ, Gainor JF, Bozkurtlar E, Uruga H, Zhao L, Gomez-Caraballo M, Hata AN, Mark EJ, Lanuti M, Engelman JA, Mino-Kenudson M. Programmed Cell Death Ligand 1 Expression in Resected Lung Adenocarcinomas: Association with Immune Microenvironment. J Thorac Oncol. 2016; 11:1869-78.

110. Inoue Y, Yoshimura K, Mori K, Kurabe N, Kahyo T, Mori H, Kawase A, Tanahashi M, Ogawa H, Inui $\mathrm{N}$, Funai K, Shinmura K, Niwa H, et al. Clinical significance of PD-L1 and PD-L2 copy number gains in non-small-cell lung cancer. Oncotarget. 2016; 7:32113-28. https://doi. org/10.18632/oncotarget.8528.

111. Ji M, Liu Y, Li Q, Li X, Ning Z, Zhao W, Shi H, Jiang J, Wu C. PD-1/PD-L1 expression in non-small-cell lung cancer and its correlation with EGFR/KRAS mutations. Cancer Biol Ther. 2016; 17:407-13.

112. Shimoji M, Shimizu S, Sato K, Suda K, Kobayashi Y, Tomizawa K, Takemoto T, Mitsudomi T. Clinical and pathologic features of lung cancer expressing programmed cell death ligand 1 (PD-L1). Lung Cancer. 2016; 98:69-75.

113. Song Z, Yu X, Cheng G, Zhang Y. Programmed death-ligand 1 expression associated with molecular characteristics in surgically resected lung adenocarcinoma. J Transl Med. 2016; 14:188.

114. Takada K, Okamoto T, Shoji F, Shimokawa M, Akamine T, Takamori S, Katsura M, Suzuki Y, Fujishita T, Toyokawa G, Morodomi Y, Okano S, Oda Y, Maehara Y. Clinical Significance of PD-L1 Protein Expression in Surgically Resected Primary Lung Adenocarcinoma. J Thorac Oncol. 2016; 11:1879-90.

115. He Y, Rozeboom L, Rivard CJ, Ellison K, Dziadziuszko R, Yu H, Zhou C, Hirsch FR. PD-1, PD-L1 Protein Expression in Non-Small Cell Lung Cancer and Their Relationship with Tumor-Infiltrating Lymphocytes. Med Sci Monit. 2017; 23:1208-16.

116. Hirai A, Yoneda K, Shimajiri S, Kuroda K, Hanagiri T, Fujino Y, Tanaka F. Prognostic impact of programmed death-ligand 1 expression in correlation with human leukocyte antigen class I expression status in stage I adenocarcinoma of the lung. J Thorac Cardiovasc Surg. 2018; 155:382-392.e1.

117. Igawa S, Sato Y, Ryuge S, Ichinoe M, Katono K, Hiyoshi Y, Otani S, Nagashio R, Nakashima H, Katagiri M, Sasaki J, Murakumo Y, Satoh Y, Masuda N. Impact of PD-L1 Expression in Patients with Surgically Resected Non-SmallCell Lung Cancer. Oncology. 2017; 92:283-90.

118. Okita R, Maeda A, Shimizu K, Nojima Y, Saisho S, Nakata M. PD-L1 overexpression is partially regulated by EGFR/HER2 signaling and associated with poor prognosis in patients with non-small-cell lung cancer. Cancer Immunol Immunother. 2017; 66:865-76.

119. Takada K, Toyokawa G, Okamoto T, Shimokawa M, Kozuma Y, Matsubara T, Haratake N, Akamine T, Takamori S, Katsura M, Shoji F, Oda Y, Maehara Y. A Comprehensive Analysis of Programmed Cell Death Ligand-1 Expression With the Clone SP142 Antibody in Non-Small-Cell Lung Cancer Patients. Clin Lung Cancer. 2017; 18:572-582.e1.

120. Toyokawa G, Takada K, Okamoto T, Kawanami S, Kozuma Y, Matsubara T, Haratake N, Takamori S, Akamine T, Katsura M, Yamada Y, Shoji F, Baba S, et al. Relevance Between Programmed Death Ligand 1 and Radiologic Invasiveness in Pathologic Stage I Lung Adenocarcinoma. Ann Thorac Surg. 2017; 103:1750-57.

121. Uruga H, Bozkurtlar E, Huynh TG, Muzikansky A, Goto Y, Gomez-Caraballo M, Hata AN, Gainor JF, Mark EJ, Engelman JA, Lanuti MD, Mino-Kenudson M. Programmed Cell Death Ligand (PD-L1) Expression in Stage II and III Lung Adenocarcinomas and Nodal Metastases. J Thorac Oncol. 2017; 12:458-66.

122. Wu S, Shi X, Sun J, Liu Y, Luo Y, Liang Z, Wang J, Zeng $X$. The significance of programmed cell death ligand 1 expression in resected lung adenocarcinoma. Oncotarget. 2017; 8:16421-29. https://doi.org/10.18632/ oncotarget.14851.

123. Zhang M, Wang D, Sun Q, Pu H, Wang Y, Zhao S, Wang Y, Zhang Q. Prognostic significance of PD-L1 expression and18F-FDG PET/CT in surgical pulmonary squamous cell carcinoma. Oncotarget. 2017; 8:51630-40. https://doi. org/10.18632/oncotarget.18257.

124. Zhou C, Tang J, Sun H, Zheng X, Li Z, Sun T, Li J, Wang S, Zhou X, Sun H, Cheng Z, Zhang H, Ma H. PD-L1 expression as poor prognostic factor in patients with nonsquamous non-small cell lung cancer. Oncotarget. 2017; 8:58457-68. https://doi.org/10.18632/oncotarget.17022.

125. Mao Y, Li W, Chen K, Xie Y, Liu Q, Yao M, Duan W, Zhou X, Liang R, Tao M. B7-H1 and B7-H3 are independent predictors of poor prognosis in patients with non-small cell lung cancer. Oncotarget. 2015; 6:3452-61. https://doi.org/10.18632/oncotarget.3097. 
126. Cha YJ, Kim HR, Lee CY, Cho BC, Shim HS. Clinicopathological and prognostic significance of programmed cell death ligand-1 expression in lung adenocarcinoma and its relationship with p53 status. Lung Cancer. 2016; 97:73-80.

127. Geng Y, Shao Y, He W, Hu W, Xu Y, Chen J, Wu C, Jiang J. Prognostic Role of Tumor-Infiltrating Lymphocytes in Lung Cancer: a Meta-Analysis. Cell Physiol Biochem. 2015; 37:1560-71.

128. Zeng DQ, Yu YF, Ou QY, Li XY, Zhong RZ, Xie CM, $\mathrm{Hu}$ QG. Prognostic and predictive value of tumorinfiltrating lymphocytes for clinical therapeutic research in patients with non-small cell lung cancer. Oncotarget. 2016; 7:13765-81. https://doi.org/10.18632/oncotarget.7282.

129. Hu XY, Zhang W, Hu Y, Zhang Y, Gong R, Liang JY, Liu L. A meta-analysis reveals prognostic role of programmed death ligand-1 in Asian patients with non-small cell lung cancer. J Huazhong Univ Sci Technolog Med Sci. 2016; 36:313-20.

130. Zhang M, Li G, Wang Y, Wang Y, Zhao S, Haihong P, Zhao H, Wang Y. PD-L1 expression in lung cancer and its correlation with driver mutations: a meta-analysis. Sci Rep. 2017; 7:10255.

131. Zhong A, Xing Y, Pan X, Shi M, Xu H. Prognostic value of programmed cell death-ligand 1 expression in patients with non-small-cell lung cancer: evidence from an updated meta-analysis. OncoTargets Ther. 2015; 8:3595-601.

132. Pan ZK, Ye F, Wu X, An HX, Wu JX. Clinicopathological and prognostic significance of programmed cell death ligand1 (PD-L1) expression in patients with non-small cell lung cancer: a meta-analysis. J Thorac Dis. 2015; 7:462-70.

133. Zhou ZJ, Zhan P, Song Y. PD-L1 over-expression and survival in patients with non-small cell lung cancer: a metaanalysis. Transl Lung Cancer Res. 2015; 4:203-08.

134. Zhou GW, Xiong Y, Chen S, Xia F, Li Q, Hu J. Anti-PD-1/ PD-L1 antibody therapy for pretreated advanced nonsmallcell lung cancer: A meta-analysis of randomized clinical trials. Medicine (Baltimore). 2016; 95:e4611.

135. Wang A, Wang HY, Liu Y, Zhao MC, Zhang HJ, Lu ZY, Fang YC, Chen XF, Liu GT. The prognostic value of PD-L1 expression for non-small cell lung cancer patients: a metaanalysis. Eur J Surg Oncol. 2015; 41:450-56.

136. Pietra G, Vitale C, Pende D, Bertaina A, Moretta F, Falco M, Vacca P, Montaldo E, Cantoni C, Mingari MC, Moretta A, Locatelli F, Moretta L. Human natural killer cells: news in the therapy of solid tumors and high-risk leukemias. Cancer Immunol Immunother. 2016; 65:465-76.

137. Guillerey C, Huntington ND, Smyth MJ. Targeting natural killer cells in cancer immunotherapy. Nat Immunol. 2016; 17:1025-36.

138. Dammeijer F, Lievense LA, Veerman GD, Hoogsteden HC, Hegmans JP, Arends LR, Aerts JG. Efficacy of Tumor Vaccines and Cellular Immunotherapies in Non-Small-Cell
Lung Cancer: A Systematic Review and Meta-Analysis. J Clin Oncol. 2016; 34:3204-12.

139. Saka H, Kitagawa C, Ichinose $Y$, Takenoyama M, Ibata $\mathrm{H}$, Kato $\mathrm{T}$, Takami $\mathrm{K}$, Yamashita $\mathrm{M}$, Maeda $\mathrm{T}$, Takeo S, Ueda H, Okabayashi K, Nagashima S, et al. A randomized phase II study to assess the effect of adjuvant immunotherapy using $\alpha$-GalCer-pulsed dendritic cells in the patients with completely resected stage II-IIIA non-small cell lung cancer: study protocol for a randomized controlled trial. Trials. 2017; 18:429.

140. Zeltsman M, Dozier J, McGee E, Ngai D, Adusumilli PS. CAR T-cell therapy for lung cancer and malignant pleural mesothelioma. Transl Res. 2017; 187:1-10.

141. Malfettone A, Silvestris N, Saponaro C, Ranieri G, Russo A, Caruso S, Popescu O, Simone G, Paradiso A, Mangia A. High density of tryptase-positive mast cells in human colorectal cancer: a poor prognostic factor related to protease-activated receptor 2 expression. J Cell Mol Med. 2013; 17:1025-37.

142. Ribatti D, Ennas MG, Vacca A, Ferreli F, Nico B, Orru S, Sirigu P. Tumor vascularity and tryptase-positive mast cells correlate with a poor prognosis in melanoma. Eur J Clin Invest. 2003; 33:420-25.

143. Cai SW, Yang SZ, Gao J, Pan K, Chen JY, Wang YL, Wei LX, Dong JH. Prognostic significance of mast cell count following curative resection for pancreatic ductal adenocarcinoma. Surgery. 2011; 149:576-84.

144. Alì G, Boldrini L, Lucchi M, Mussi A, Corsi V, Fontanini G. Tryptase mast cells in malignant pleural mesothelioma as an independent favorable prognostic factor. J Thorac Oncol. 2009; 4:348-54.

145. Chan JK, Magistris A, Loizzi V, Lin F, Rutgers J, Osann K, DiSaia PJ, Samoszuk M. Mast cell density, angiogenesis, blood clotting, and prognosis in women with advanced ovarian cancer. Gynecol Oncol. 2005; 99:20-25.

146. Rajput AB, Turbin DA, Cheang MC, Voduc DK, Leung S, Gelmon KA, Gilks CB, Huntsman DG. Stromal mast cells in invasive breast cancer are a marker of favourable prognosis: a study of 4,444 cases. Breast Cancer Res Treat. 2008; 107:249-57.

147. Ishigami S, Natsugoe S, Tokuda K, Nakajo A, Che X, Iwashige H, Aridome K, Hokita S, Aikou T. Prognostic value of intratumoral natural killer cells in gastric carcinoma. Cancer. 2000; 88:577-83.

148. Takeuchi H, Maehara Y, Tokunaga E, Koga T, Kakeji Y, Sugimachi K. Prognostic significance of natural killer cell activity in patients with gastric carcinoma: a multivariate analysis. Am J Gastroenterol. 2001; 96:574-78.

149. Coca S, Perez-Piqueras J, Martinez D, Colmenarejo A, Saez MA, Vallejo C, Martos JA, Moreno M. The prognostic significance of intratumoral natural killer cells in patients with colorectal carcinoma. Cancer. 1997; 79:2320-28.

150. González FM, Vargas JA, López-Cortijo C, Castejón R, Gorriz C, Ramírez-Camacho R, Millán I, Durántez A. 
Prognostic significance of natural killer cell activity in patients with laryngeal carcinoma. Arch Otolaryngol Head Neck Surg. 1998; 124:852-56.

151. Zheng X, Song X, Shao Y, Xu B, Chen L, Zhou Q, Hu W, Zhang D, Wu C, Tao M, Zhu Y, Jiang J. Prognostic role of tumor-infiltrating lymphocytes in gastric cancer: a meta-analysis. Oncotarget. 2017; 8:57386-98. https://doi. org/10.18632/oncotarget.18065.

152. Mao Y, Qu Q, Chen X, Huang O, Wu J, Shen K. The Prognostic Value of Tumor-Infiltrating Lymphocytes in Breast Cancer: A Systematic Review and Meta-Analysis. PLoS One. 2016; 11:e0152500.

153. Yao W, He JC, Yang Y, Wang JM, Qian YW, Yang T, Ji L. The Prognostic Value of Tumor-infiltrating Lymphocytes in Hepatocellular Carcinoma: a Systematic Review and Metaanalysis. Sci Rep. 2017; 7:7525.

154. Li J, Wang J, Chen R, Bai Y, Lu X. The prognostic value of tumor-infiltrating $\mathrm{T}$ lymphocytes in ovarian cancer. Oncotarget. 2017; 8:15621-31. https://doi.org/10.18632/ oncotarget. 14919.

155. Mei Z, Liu Y, Liu C, Cui A, Liang Z, Wang G, Peng H, Cui L, Li C. Tumour-infiltrating inflammation and prognosis in colorectal cancer: systematic review and metaanalysis. Br J Cancer. 2014; 110:1595-605.

156. Shang B, Liu Y, Jiang SJ, Liu Y. Prognostic value of tumorinfiltrating FoxP3+ regulatory T cells in cancers: a systematic review and meta-analysis. Sci Rep. 2015; 5:15179.

157. Schmidt M, Böhm D, von Törne C, Steiner E, Puhl A, Pilch H, Lehr HA, Hengstler JG, Kölbl H, Gehrmann M. The humoral immune system has a key prognostic impact in node-negative breast cancer. Cancer Res. 2008; 68:5405-13.

158. Siliņa K, Rulle U, Kalniņa Z, Linē A. Manipulation of tumour-infiltrating $\mathrm{B}$ cells and tertiary lymphoid structures: a novel anti-cancer treatment avenue? Cancer Immunol Immunother. 2014; 63:643-62.

159. Shen M, Hu P, Donskov F, Wang G, Liu Q, Du J. Tumorassociated neutrophils as a new prognostic factor in cancer: a systematic review and meta-analysis. PLoS One. 2014; 9:e98259.

160. Takahashi K, Isobe T, Ohtsuki Y, Akagi T, Sonobe H, Okuyama T. Immunohistochemical study on the distribution of alpha and beta subunits of S-100 protein in human neoplasm and normal tissues. Virchows Arch B Cell Pathol Incl Mol Pathol. 1984; 45:385-96.

161. Bell D, Chomarat P, Broyles D, Netto G, Harb GM, Lebecque S, Valladeau J, Davoust J, Palucka KA, Banchereau J. In breast carcinoma tissue, immature dendritic cells reside within the tumor, whereas mature dendritic cells are located in peritumoral areas. J Exp Med. 1999; 190:1417-26.

162. Iwamoto M, Shinohara H, Miyamoto A, Okuzawa M, Mabuchi H, Nohara T, Gon G, Toyoda M, Tanigawa N. Prognostic value of tumor-infiltrating dendritic cells expressing CD83 in human breast carcinomas. Int J Cancer. 2003; 104:92-97.

163. Abdel-Rahman O. Correlation between PD-L1 expression and outcome of NSCLC patients treated with anti-PD-1/ PD-L1 agents: A meta-analysis. Crit Rev Oncol Hematol. 2016; 101:75-85.

164. Aguiar PN Jr, Santoro IL, Tadokoro H, de Lima Lopes G, Filardi BA, Oliveira P, Castelo-Branco P, Mountzios G, de Mello RA. A pooled analysis of nivolumab for the treatment of advanced non-small-cell lung cancer and the role of PD-L1 as a predictive biomarker. Immunotherapy. 2016; 8:1011-9.

165. Su Q, Sun Z, Zhang C, Hou Y, Cao B. PD-1/PD-L1 antibodies efficacy and safety versus docetaxel monotherapy in advanced NSCLC patients after first-line treatment option: systems assessment. Oncotarget. 2017; 8:59677-89. https://doi.org/10.18632/oncotarget.19641.

166. Hirsch FR, McElhinny A, Stanforth D, Ranger-Moore J, Jansson M, Kulangara K, Richardson W, Towne P, Hanks D, Vennapusa B, Mistry A, Kalamegham R, Averbuch S, et al. PD-L1 Immunohistochemistry Assays for Lung Cancer: Results from Phase 1 of the Blueprint PD-L1 IHC Assay Comparison Project. J Thorac Oncol. 2017; 12:208-22.

167. Kerr KM, Hirsch FR. Programmed Death Ligand-1 Immunohistochemistry: friend or Foe? Arch Pathol Lab Med. 2016; 140:326-31.

168. Hendry S, Salgado R, Gevaert T, Russell PA, John T, Thapa B, Christie M, van de Vijver K, Estrada MV, Gonzalez-Ericsson PI, Sanders M, Solomon B, Solinas C, et al. Assessing Tumor-Infiltrating Lymphocytes in Solid Tumors: A Practical Review for Pathologists and Proposal for a Standardized Method from the International ImmunoOncology Biomarkers Working Group: Part 2: TILs in Melanoma, Gastrointestinal Tract Carcinomas, Non-Small Cell Lung Carcinoma and Mesothelioma, Endometrial and Ovarian Carcinomas, Squamous Cell Carcinoma of the Head and Neck, Genitourinary Carcinomas, and Primary Brain Tumors. Adv Anat Pathol. 2017; 24:311-35.

169. Hendry S, Salgado R, Gevaert T, Russell PA, John T, Thapa B, Christie M, van de Vijver K, Estrada MV, Gonzalez-Ericsson PI, Sanders M, Solomon B, Solinas C, et al. Assessing Tumor-infiltrating Lymphocytes in Solid Tumors: A Practical Review for Pathologists and Proposal for a Standardized Method From the International Immunooncology Biomarkers Working Group: Part 1: Assessing the Host Immune Response, TILs in Invasive Breast Carcinoma and Ductal Carcinoma In Situ, Metastatic Tumor Deposits and Areas for Further Research. Adv Anat Pathol. 2017; 24:235-51.

170. Galon J, Costes A, Sanchez-Cabo F, Kirilovsky A, Mlecnik B, Lagorce-Pagès C, Tosolini M, Camus M, Berger A, Wind P, Zinzindohoué F, Bruneval P, Cugnenc PH, et al. Type, density, and location of immune cells within human colorectal tumors predict clinical outcome. Science. 2006; 313:1960-64. 
171. Galon J, Mlecnik B, Bindea G, Angell HK, Berger A, Lagorce C, Lugli A, Zlobec I, Hartmann A, Bifulco C, Nagtegaal ID, Palmqvist R, Masucci GV, et al. Towards the introduction of the 'Immunoscore' in the classification of malignant tumours. J Pathol. 2014; 232:199-209.

172. Donnem T, Kilvaer TK, Andersen S, Richardsen E, Paulsen EE, Hald SM, Al-Saad S, Brustugun OT, Helland A, Lund-Iversen M, Solberg S, Gronberg BH, Wahl SG, et al. Strategies for clinical implementation of TNM-Immunoscore in resected nonsmall-cell lung cancer. Ann Oncol. 2016; 27:225-32.
173. Gentles AJ, Newman AM, Liu CL, Bratman SV, Feng W, Kim D, Nair VS, Xu Y, Khuong A, Hoang CD, Diehn M, West RB, Plevritis SK, Alizadeh AA. The prognostic landscape of genes and infiltrating immune cells across human cancers. Nat Med. 2015; 21:938-45.

174. Kadara H, Choi M, Zhang J, Parra ER, Rodriguez-Canales J, Gaffney SG, Zhao Z, Behrens C, Fujimoto J, Chow C, Yoo Y, Kalhor N, Moran C, et al. Whole-exome sequencing and immune profiling of early-stage lung adenocarcinoma with fully annotated clinical follow-up. Ann Oncol. 2017; 28:75-82. 